\title{
30 YEARS OF THE MINERALOCORTICOID RECEPTOR Nongenomic effects via the mineralocorticoid receptor
}

\author{
Stefanie Ruhs, Alexander Nolze, Ralf Hübschmann and Claudia Grossmann \\ Julius Bernstein Institute of Physiology, Martin Luther University Halle-Wittenberg, Halle, Germany
}

Correspondence should be addressed to C Grossmann Email claudia.grossmann@medizin. uni-halle.de

\begin{abstract}
The mineralocorticoid receptor (MR) belongs to the steroid hormone receptor family and classically functions as a ligand-dependent transcription factor. It is involved in water-electrolyte homeostasis and blood pressure regulation but independent from these effects also furthers inflammation, fibrosis, hypertrophy and remodeling in cardiovascular tissues. Next to genomic effects, aldosterone elicits very rapid actions within minutes that do not require transcription or translation and that occur not only in classical MR epithelial target organs like kidney and colon but also in nonepithelial tissues like heart, vasculature and adipose tissue. Most of these effects can be mediated by classical MR and its crosstalk with different signaling cascades. Near the plasma membrane, the MR seems to be associated with caveolin and striatin as well as with receptor tyrosine kinases like EGFR, PDGFR and IGF1R and G proteincoupled receptors like AT1 and GPER 1, which then mediate nongenomic aldosterone effects. GPER1 has also been named a putative novel MR. There is a close interaction and functional synergism between the genomic and the nongenomic signaling so that nongenomic signaling can lead to long-term effects and support genomic actions. Therefore, understanding nongenomic aldosterone/MR effects is of potential relevance for modulating genomic aldosterone effects and may provide additional targets for intervention.
\end{abstract}
Key Words
- cardiovascular
- corticosteroids
- growth factor receptors
- aging
- renin-angiotensin system

\section{Early milestones in aldosterone research}

In 1953 aldosterone was isolated and characterized by Simpson and Tait and subsequently in 1960 genomic steroid actions were described (Clever \& Karlson 1960). Already very early on, aldosterone effects that were very rapid and therefore could not be reconciled with a genomic mechanism were described (Ganong \& Mulrow 1958, Klein \& Henk 1964, Spach \& Streeten 1964, Fujii et al. 1990). These effects of aldosterone included rapid flux of ions in erythrocytes and the kidney, stimulation of $\mathrm{Na}^{+}-\mathrm{K}^{+}$pump activity and changes in cardiovascular parameters including a decrease in cardiac output and an increase in peripheral resistance. However, neither their nongenomic nor their nonepithelial origin was fully appreciated and it took until 1984 for a nongenomic mechanism to be demonstrated (Moura \& Worcel 1984). Shortly after in 1987 the classical MR was cloned and characterized (Arriza et al. 1987). 
Beginning in the 1990s, nongenomic signaling effects were investigated on a cellular level and a membrane receptor for aldosterone was postulated. Based on the findings that actinomycin $\mathrm{D}$ and cycloheximide were not able to block the influence of aldosterone on the activity of the sodium-proton exchanger and on cell volume in HML cells, a nongenomic signaling mechanism was deduced by Wehling and coworkers (Wehling et al. 1991, 1992, Christ et al. 1994, Wildling et al. 2008). Because glucocorticoids were less effective to induce these effects and MR antagonists could not block them, the existence of a new membrane aldosterone receptor was postulated. Although exhibiting some inconsistencies, data on rapid calcium and cAMP signaling in skin cells of global MR knockout mice seemed to support this hypothesis (Haseroth et al. 1999). Several attempts were made to isolate and characterize such an aldosterone specific membrane receptor from HML and porcine kidney membranes but never completely convincingly succeeded (Wehling et al. 1991, 1992, Eisen et al. 1994, Wildling et al. 2008). Thereafter, it was shown that many of the nongenomic aldosterone effects seem to depend on classical MR (Liu et al. 2003, Callera et al. 2005b, McEneaney et al. 2010a). In cells without endogenous $\mathrm{MR}$, many of the rapid signaling effects like activation of MAP kinases could only be detected after transfection of an MR expression plasmid. Expressing exclusively the $\mathrm{E} / \mathrm{F}$ domain of the MR was sufficient for the induction of rapid aldosterone effects (Grossmann et al. 2005, 2008). Additionally, it was shown that some aldosterone effects cannot be blocked by spironolactone but by other MR antagonists like $\mathrm{K}^{+}$canrenoate or RU28313 so that ineffectiveness of spironolactone does not necessarily mean that the classical MR is not involved in an effect (Alzamora et al. 2000, Mihailidou \& Funder 2005). Nevertheless, aldosterone was still able to induce rapid signaling if aldosterone was conjugated to BSA or PEG and in cells devoid of classical MR so that both MR-dependent and -independent mechanisms seem to lead to nongenomic aldosterone effects (Le Moellic et al. 2004, Grossmann et al. 2005, Wildling et al. 2008, Ashton et al. 2015). While early works focused on characterizing transporters and intracellular signaling molecules like calcium ions and kinases (Funder 2005, Grossmann \& Gekle 2009), more recent studies have identified additional interaction partners of the MR at the plasma membrane.

\section{Interaction partners at the plasma membrane}

For the rapid MR-dependent aldosterone effects, a localization of the classical MR near the plasma membrane has been indicated in several studies (Grossmann et al. 2010, Callera et al. 2011, Coutinho et al. 2014, Ashton et al. 2015). Since the MR lacks a palmitoylation site that has been identified as transmembrane domain in other steroid receptors, it does not seem to be directly inserted into the plasma membrane. Most likely this is achieved by an association of MR to the cytosolic side of the plasma membrane by scaffolding proteins that are associated to or inserted in the cell membrane (Grossmann et al. 2010).

\section{Scaffolding proteins}

Recently, striatin and caveolin-1 (CAV1) were identified as candidates for such scaffolding proteins (Coutinho et al. 2014, Ashton et al. 2015). For both proteins evidence for

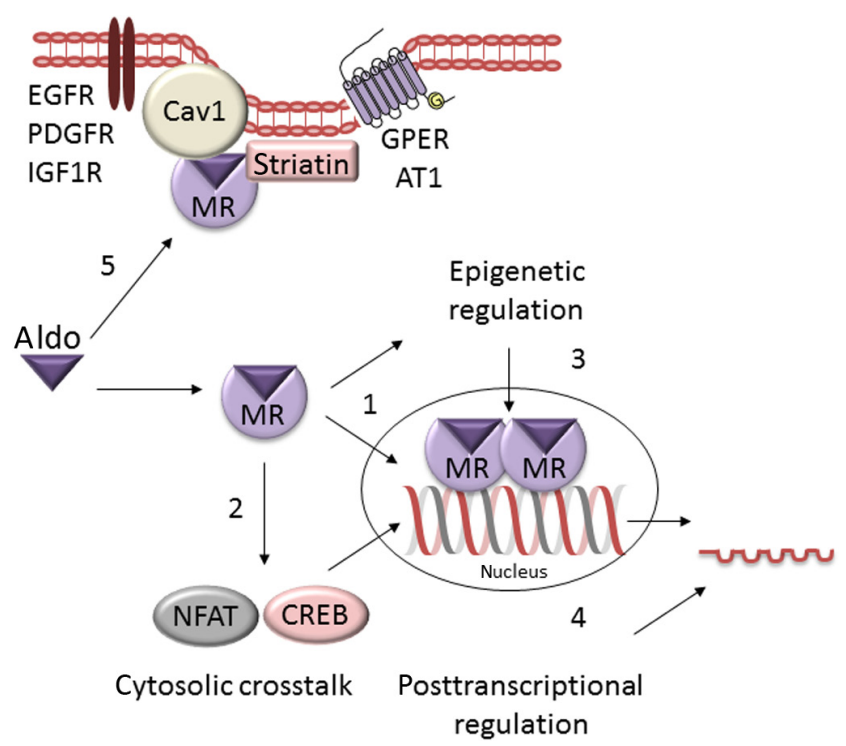

Figure 1

Aldosterone/MR signaling. Aldosterone (aldo) has several mechanisms of action. (1) It can bind to cytosolic MR and initiate translocation of MR into the nucleus, where the MR homodimerizes and acts as a transcription factor. (2) Additionally, aldosterone and MR can initiate a crosstalk with other cytosolic signaling pathways, like for example NFAT and CREB signaling, which ultimately may affect genomic signaling. (3) Genomic MR signaling may be influenced by epigenetic regulation by histone modification or promoter methylation and also by (4) posttranscriptional regulation for example by microRNAs. (5) Aldosterone can also bind to MR attached to the plasma membrane by scaffolding proteins like Cav1 and striatin. There it may elicit nongenomic effects by interacting with receptors, i.e. receptor tyrosine kinases like EGFR, PDGFR and IGF1R or GPCR like AT1 or GPER1.
(C) 2017 Society for Endocrinology Printed in Great Britain
Published by Bioscientifica Ltd 
an involvement in nongenomic signaling as part of a larger membrane complex exists (Fig. 1).

Striatin Striatin is a scaffolding protein that contains several protein-binding domains, which enable it to interact with and activate different signal transduction molecules. These domains include a caveolin binding motif that attaches it to the plasma membrane, a coiled-coil-domain, a $\mathrm{Ca}^{++}$-calmodulin-binding site and WD-repeat domains for interactions with Goi proteins and PP2A phosphatase (Hwang \& Pallas 2014). In endothelial cells and murine heart tissue, complexes between striatin and MR have been described that can be disrupted by aldosterone but cannot be restored by spironolactone (Pojoga et al. 2012, Ashton et al. 2015). Activation of MR by high levels of aldosterone increases striatin levels in vascular cells and in tissues of mouse models with elevated aldosterone concentrations (Ricchiuti et al. 2011, Pojoga et al. 2012). Lowering striatin levels in endothelial cells reduces nongenomic aldosterone/ MR-dependent ERK phosphorylation without affecting EGF-induced ERK phosphorylation or genomic MR signaling (Coutinho et al. 2014). The relevance of striatin for MR signaling is further suggested by the analysis of heterozygous striatin $\mathrm{KO}$ mice with low striatin levels and salt sensitive blood pressure. In this model, pAKT/AKT ratio, another potential nongenomic MR signaling pathway, is reduced while MR expression and genomic signaling are increased (Garza et al. 2014). Consequently, striatin seems to play a role in nongenomic MR signaling. A similar role in nongenomic steroid receptor signaling has been described for striatin in estrogen receptor alpha signaling, where striatin is involved in the activation of AKT and eNOS and estrogenmediated protection of arteries after injury (Lu et al. 2004, Bernelot Moens et al. 2012).

Caveolin Caveolins are membrane-bound scaffolding proteins enriched in caveolae that help to form microdomains for signal transduction, i.e. for PI3K/AKT signaling, ERK1/2, NO, eNOS, G protein-coupled receptors (GPCRs), tyrosine kinases and PKC (Yang et al. 2016). For other steroid receptors, caveolin acts as a control point for crosstalk with other signaling pathways (Igarashi et al. 2013). Both AT1 and MR coimmunoprecipitate with CAV1 in rat, mouse and human tissues and the MR contains a caveolin binding motif in the middle of n-terminal domain (between aa 450 and 460 (FPFMDGSYFSF) (Ushio-Fukai \& Alexander 2006, Pojoga et al. 2010b,
Coutinho et al. 2014). Aldosterone induces caveolin-1 expression in endothelial cells (BAEC), an effect that can be inhibited by spironolactone (Igarashi et al. 2013). In Cav1 KO mice an interaction between MR and striatin is no longer detectable and MR expression is reduced (Pojoga et al. 2010a, Coutinho et al. 2014). Conversely, during sodium load, CAV1 and MR expression are increased and more complexes between the two can be detected (Ricchiuti et al. 2011). There are several indications that Cav1 is associated with MR signaling although the exact mechanisms remain to be investigated. In Cav1 KO mice on a high salt diet, MR blockade increases blood pressure and vascular contraction but reduces eNOS expression and vasorelaxation so that MR seems to play a beneficial role (Pojoga et al. 2010a). Additionally, Cav1 $\mathrm{KO}$ mice and carriers of Cav1 gene variants are prone to insulin resistance, dyslipidemia and other metabolic abnormalities probably due to impaired aldosterone/MR signaling (Pojoga et al. 2011, Baudrand et al. 2016). After challenge with L-NAME and angiotensin II (angII), Cav1 KO mice showed disturbed MR signaling with reduced MR and PAI-1 expression and were protected from myocardial damage despite higher increases in systolic blood pressure than WT mice (Pojoga et al. 2010b).

Overall, there are indications that both striatin and caveolin are involved in nongenomic MR signaling by associating classical MR to the plasma membrane. Additionally, CAV1 is an excellent candidate for linking the MR to membrane receptors like receptor tyrosine kinases and also GPCRs, for which transactivation or a crosstalk with classical MR has been demonstrated. Furthermore, CAV1 is also associated with many other molecules like eNOS and c-SRC, which are activated as a result of rapid aldosterone/MR signaling, suggesting that a larger membrane signaling complex exists for mediating various nongenomic aldosterone effects and that the classical MR is an integral part of this complex.

\section{Membrane receptors}

As part of rapid MR signaling, transactivation of receptor tyrosine kinases including EGFR, PDGFR and IGF1R has been described. For GPCRs even more complex synergistic activities have been reported especially for AT1 and GPER1. GPER1 has even been declared an aldosterone receptor although direct binding of aldosterone has not been shown. All of these receptors are located in close proximity to the putative MR scaffolding proteins described previously and they have been mostly studied as modulators of pathological MR effects.

Published by Bioscientifica Ltd. 
EGFR Of themembrane receptor tyrosine kinasesinvolved in aldosterone signaling, the epidermal growth factor receptor (EGFR) seems to be of special importance as a signal integrator for both physiological and pathophysiological aldosterone effects. The EGFR is associated to CAV1 and can be transactivated by aldosterone/MR either through a C-SRC- or ROS-dependent mechanism, which then leads to downstream MAP kinase and/or PI3 kinase signaling (Mazak et al. 2004, Grossmann et al. 2005, 2008, McEneaney et al. 2007, Huang et al. 2009). Importantly, the EGFR cascade is also linked to other important signaling components of aldosterone like $\mathrm{G}$ protein-coupled AT1 and GPER signaling and PDGFR activation. Physiological MR effects mediated via EGFR include processes that enhance surface expression of different transporters like $\mathrm{ENaC}$ (McEneaney et al. 2007), NHE1 (Gekle et al. 2002) or NHE3 (Drumm et al. 2006) in epithelial tissues. Pathophysiological MR actions mediated by EGFR include proinflammatory effects in vessels, where aldosterone can increase lipoxygenase expression via MAPK activation (Limor et al. 2009) and where enhanced TGFbeta, ICAM1 and collagen I expression in VSMCs of aged rats can be attenuated by MR or MAP kinase inhibitors (Krug et al. 2010). In conjunction with AT1 signaling, aldosterone via EGFR can also induce a mitogenic response and enhanced cell migration (Min et al. 2005, Montezano et al. 2008). Transactivation of EGFR by aldosterone/MR can furthermore aggravate fibrosis through induction of fibroblast proliferation via PDGFR, PI3K and MAP kinase signaling shown in kidney and by augmenting collagen synthesis in vascular and HEK cells in a favorable micromilieu (Gekle et al. 2007, Huang et al. 2012). A truncated MR variant without DNAbinding domain is sufficient to enhance extracellular matrix production, which supports a nongenomic nature of the effect (Grossmann et al. 2008). In the kidney, aldosterone via MR additionally induces mesangial cell proliferation via ROS-dependent activation of EGFR, leading to combined ERK1/2 and PI3K/mTOR signaling (Huang et al. 2009). There is a close interaction between genomic and nongenomic aldosterone signaling because aldosterone/MR can both transactivate the EGFR and enhance its expression (Dorrance et al. 2001, Nakano et al. 2005, Meinel et al. 2013). Furthermore, nongenomic aldosterone-mediated ERK1/2 phosphorylation seems to enhance MR nuclear shuttling and thereby transactivation activity (Grossmann et al. 2005).

PDGFR Another receptor tyrosine kinase located in caveolae and involved in aldosterone signaling is the platelet-derived growth factor receptor (PDGFR). It can also be transactivated by MR and AT1, which then lead to C-SRC activation, increased NADPH oxidase activity and cell migration (Montezano et al. 2008). Additionally, PDGFR-C-SRC signaling is involved in aldosteronedependent proinflammatory responses, namely increased ICAM and VCAM expression and stimulation of monocyte adhesion to VSMCs. Together with the EGFR, PDGFR induces fibroblast proliferation in the kidney (Huang et al. 2012). Interestingly, PDGF was shown to stimulate nuclear MR translocation in pulmonary artery smooth muscle cells as well as cell proliferation (Preston et al. 2013) indicating that nongenomic aldosterone effects support genomic ones.

IGF1R A third receptor tyrosine kinase, interacting with aldosterone signaling is the insulin-like-growth factor 1 receptor (IGF1R), which has been investigated in renal epithelial cells and in fibroblasts of different origin (Holzman et al. 2007, Mitts et al. 2010). Its transactivation by aldosterone in cardiac fibroblasts cannot be inhibited by spironolactone, involves activation of $\mathrm{G} \alpha 13$ and c-src and leads to enhanced elastogenesis (Bunda et al. 2007, 2009). Likewise in renal fibroblasts, a rapid MR-independent fibronectin synthesis that requires C-SRC mediated IGF1R transactivation with subsequent ERK1/2 phosphorylation has been described (Chen et al. 2013). Besides transactivating IGF1R, aldosterone again can genomically increase its expression (and that of hybrid receptor), leading to VSMC growth, migration, protein synthesis and insulin resistance (Cascella et al. 2010, Sherajee et al. 2012). In a diabetes mouse model with over-expression of aldosterone synthase, an increase in IGF1R expression was associated with protection against diabetes-associated cardiac changes (Fazal et al. 2014), suggesting that in this scenario nongenomic signaling may even exert some beneficial effects.

AT1 Besides receptor tyrosine kinases, GPCRs are also important interaction partners of nongenomic aldosterone/MR signaling. For angII receptor I (AT1), a complex interaction with aldosterone/MR signaling on different levels is reported in literature and spironolactone, for example, can inhibit angII-mediated pathological effects by improving cardiac and vascular changes, including fibrosis, hypertrophy and oxidative stress in rats (Ullian et al. 1992, 1996, Fiebeler et al. 2001, Virdis et al. 2002, Neves et al. 2003, 2005). Besides a genomic component whereby aldosterone regulates ACE

Published by Bioscientifica Ltd. 
(and thereby angII synthesis), MR and AT1 expression in the cardiovascular system, MR and AT1 signaling cascades also interact on a nongenomic level (Zennaro et al. 1996, Sugiyama et al. 2005, Hirono et al. 2007, Tsai et al. 2013). In VSMCs this was shown by demonstrating a synergistic effect of angII and aldosterone on ERK1/2 phosphorylation that results in cell proliferation, migration and cell senescence (Mazak et al. 2004, Min et al. 2005, 2007). In the brain the crosstalk between MR and AT1 and MAP kinase signaling is involved in increased sympathetic drive and hypertension (Xue et al. 2011, Zhang et al. 2012). As a second common signaling mechanism, IGF1R and redox-dependent activation of kinases like RHOA kinase was described, which support VSMC migration (Montezano et al. 2008). Furthermore, aldosteroneinduced rapid vasoconstriction in coronary arterioles was dependent on AT1 and possibly AT1 dimer formation but in this case, spironolactone was not able to block the effect of aldosterone (Kushibiki et al. 2007, Yamada et al. 2008). While aldosterone-dependent phosphorylation of ERK1/2, JNK and NFkB requires AT1, angII-dependent activation of $\mathrm{NF \kappa B}$ requires MR (Lemarie et al. 2008). Additionally, transactivation of the MR by angII (and AT1) with subsequent regulation of MR-dependent genes has been demonstrated (Xiao et al. 2004, Jaffe \& Mendelsohn 2005). Relevance of $G$ protein-coupled receptor signaling for pathological aldosterone effects is demonstrated by the attenuation of cardiac damage including ROS production, myocyte cell death and hypertrophy by either MR or AT1 blockade and the involvement of GRK2 and GRK5 (Cannavo et al. 2016).

GPER1 Another G protein-coupled receptor with special relevance for nongenomic aldosterone signaling is G protein-coupled estrogen receptor 1 (GPER1), alias GPR30, which is best known for conveying nongenomic estrogen effects in different model systems but has also been proposed to be a novel aldosterone receptor. As estrogen receptor in the cardiovascular system, it influences vascular tone through modulation of p-eNOS/ eNOS and pERK/ERK ratios as well as apoptosis via PI3K, c-SRC and EGFR and also influences PKA (Filardo et al. 2000, 2002, Meyer et al. 2016). A protective role in pulmonary hypertension, atherosclerosis and diabetes has been postulated (Barton \& Prossnitz 2015, Prossnitz $\&$ Hathaway 2015).

An interaction between aldosterone, MR and GPER1 signaling was first described in VSMCs by Gros and coworkers who later showed that ERK1/2 phosphorylation was stimulated by aldosterone via GPER1 and MR and could be inhibited by eplerenone or the GPER1 antagonist G15 (Gros et al. 2007, 2011). Likewise, apoptosis induction via PI3K, ERK1/2 as well as MLC phosphorylation was enhanced by aldosterone via both receptors. Interestingly, GPER1 had no effect on corticosterone- or angII-mediated ERK1/2 phosphorylation (Gros et al. 2011). In endothelial cells aldosterone and the GPER1 agonist G1 both induced ERK phosphorylation and also apoptosis. These experiments suggest a crosstalk between aldosterone and GPER1 signaling but do not prove a direct binding or interaction between aldosterone and GPER1.

Further support for a crosstalk comes from experiments showing that nanomolar concentration of aldosterone are able to enhance angII-mediated vasoconstriction in human coronary microarteries in a GPER1- and EGFRdependent manner (Batenburg et al. 2012). In mesenteric resistance arteries, aldosterone led to enhanced maximal phenylephrine-induced vasocontraction that could be reversed by GPER1 inhibitor and to reduced acetylcholineinduced vasorelaxation depending on MR and GPER1 (Ferreira et al. 2015). Likewise, vasocontraction in diabetic $\mathrm{db} / \mathrm{db}$ mice in response to phenylephrine could be reduced by MR or GPER1 inhibitors, however, aldosterone-induced vasorelaxation was only dependent on MR (Ferreira et al. 2015). Furthermore, aldosterone could endotheliumdependently inhibit phenylephrine-mediated vasoconstriction of aortic rings via GPER1 (Gros et al. 2013). This suggests that the effects of aldosterone on vascular tone and function are complex and dependent on both receptors MR and GPER1 and the dominant cell type, i.e. endothelial and vascular smooth muscle cells. Interestingly, striatin does not only serve as a scaffolding protein for MR but also for GPER1; and MR-striatin complexes can be disrupted by G1 and restored by the GPER antagonist G36 but not by spironolactone (Ashton et al. 2015).

Experiments in other organs suggest that GPER1 also plays a role in nongenomic aldosterone signaling in heart, kidney and in tumors. However, although pegylated aldosterone could induce ERK1/2 phosphorylation and superoxide production in $\mathrm{H} 9 \mathrm{c} 2$ cells, it was not able to aggravate the infarct size in an ex vivo rat model of myocardial infarction like unmodified aldosterone. This indicates that GPER1 activation at the membrane is not sufficient to trigger pathophysiological aldosterone effects in myocardial reperfusion injury (Ashton et al. 2015). Furthermore, in rat cardiomyocytes, aldosterone and G1 could enhance sodium bicarbonate cotransporter (NBC) activity depending on GPER1, EGFR, ROS production and

Published by Bioscientifica Ltd. 
AKT stimulation (De Giusti et al. 2015). In cardiac vagal neurons vagal tone and thereby bradycardia was increased via GPER1 and calcium signaling (Brailoiu et al. 2013, De Giusti et al. 2015) while in the kidney, a sensitization of renal connecting tubule glomerular feedback by aldosterone involved nongenomic effects via GPER1, classical MR and sodium-proton exchanger 1 (NHE1) (Ren et al. 2014). In addition, aldosterone induced cell proliferation and migration of tumor cells via GPER1, and it also induced pulmonary tumor spread that could be inhibited by spironolactone and GPER1 inhibition (Feldman et al. 2016). Functionally, MR and GPER1 contribute to proliferation and migration of breast and endothelial cancer cells by mediating an upregulation of NHE1 (Rigiracciolo et al. 2016). Consequently, there are many indications for functional involvement of GPER1 in rapid aldosterone/MR signaling (Ashton et al. 2015) (Fig. 2). However, although estradiol was shown to bind to the plasma membrane fraction in GPER1 over-expressing HEK cells or SKBr3 cells with endogenous GPER1 expression, no binding of aldosterone was found and displacement of $3 \mathrm{H}$-estradiol was also not possible. In these cellular systems, aldosterone elicited no recruitment of GTPyS to the plasma membrane, which would have supported a direct GPER1 activation by aldosterone as a ligand (Cheng et al. 2014). It has also not been fully elucidated why specific MR antagonists sometimes are able to block G1 and GPER1 effects so that further work is required to establish the exact role of GPER1 for nongenomic aldosterone signaling.

In summary, nongenomic aldosterone signaling often seems to rely on classical MR and a crosstalk with membrane-associated signaling cascades, including receptor tyrosine kinase and GPCR pathways. Although many participating signaling components have been identified, the precise spatial and temporal sequence of events has not been elucidated. Also the existence and identity of a possible additional aldosterone receptor is still not clear.

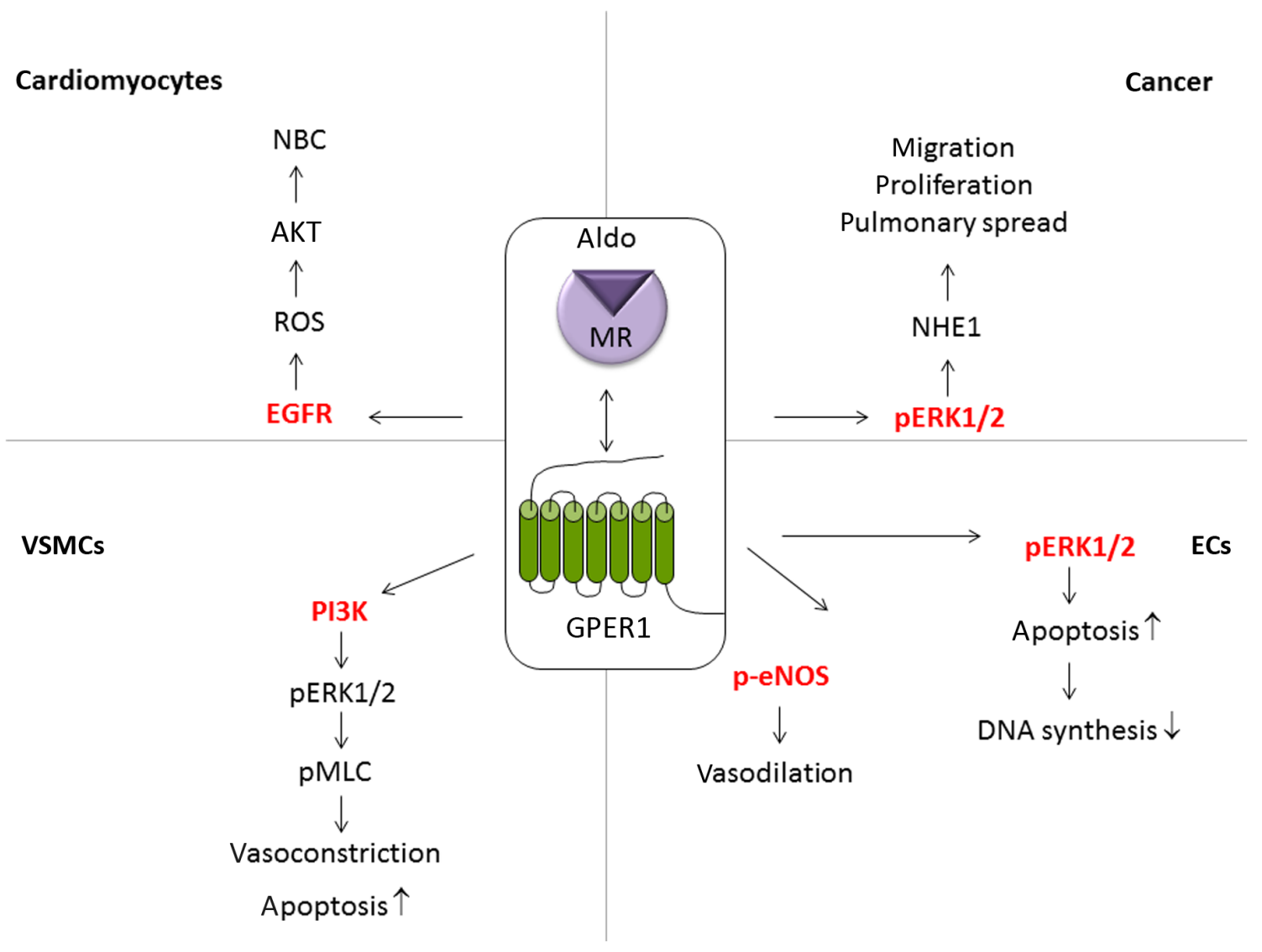

Figure 2

Functional interaction between aldosterone and GPER1. There are many indications for a functional interaction between aldosterone/MR and GPER1 signaling, especially in cardiovascular cells (endothelial cells (ECs), vascular smooth muscle cells (VSMCs) and cardiomyocytes) as well as in tumor cells. $\mathrm{NBC}$, sodium bicarbonate cotransporter; $\mathrm{PMLC}$, phosphorylated myosin light chain. 


\section{Target tissues of nongenomic MR effects}

Nongenomic MR signaling has been mostly studied as modulator of physiological and pathological genomic MR effects. Consequently, they have been especially well characterized not only in classical epithelial MR target organs like the kidney but also in cardiovascular tissues. They are often involved in ion transport but can also facilitate pathological MR effects that lead to inflammation, fibrosis and impaired tissue and organ function.

\section{Nongenomic aldosterone effects in the kidney}

The MR is best known for its effects in classical epithelial tissues like kidney, where it increases sodium reabsorption and potassium secretion through genomic changes in ion transporters like epithelial sodium channel $(\mathrm{ENaC})$, $\mathrm{Na}^{+}-\mathrm{K}^{+}$-ATPase and sodium-proton exchanger (NHE). The abundance of transporters at the plasma membrane is stabilized through aldosterone-dependent expression of proteins like SKG1, GILZ, CNKSR3 and ubiquitin-specific protease 2-45 (Oberfeld et al. 2011). In addition, a rapid increase in transport activity within minutes that cannot be explained by transcriptional regulation was detected for many of the transporters, suggesting that nongenomic effects enhance genomic effects by ensuring their early start or by perhaps functioning as feedback loops.

ENaC ENaC consists of three subunits and sodium reabsorption depends on the surface abundance of the subunits and their open probability. Genomically, aldosterone directly regulates $\mathrm{ENaC} \alpha$ expression, which facilitates sodium reabsorption. Via a genomic regulation of SGK1 expression and activity, aldosterone leads to phosphorylation of the ubiquitin ligase, NEDD4-2, which abolishes ubiquitination and degradation of $\mathrm{ENaC}$ subunits beta and gamma. Furthermore SGK is involved in phosphorylation of regulatory proteins that facilitate trafficking of ENaC subunits to the cell surface (Liang et al. 2010). Besides genomically controlling the expression and degradation of $\mathrm{ENaC}$ subunits, aldosterone also influences subcellular trafficking of $\mathrm{ENaC}$ subunits to the cell membrane and influences $\mathrm{ENaC}$ open probability by nongenomic mechanisms. Through activation of EGFR, PKC and PKD, rapid trafficking of ENaC subunits to the apical membrane followed by prolonged increased apical membrane expression and activity was reported
(Loffing et al. 2001, McEneaney et al. 2008, 2010b, Kusche-Vihrog et al. 2008, Dooley et al. 2013). Subcellular trafficking seems to be modulated by members of the RAS GTPase superfamily and associated kinases that are known to modulate cytoplasmic cytoskeleton structure (Karpushev et al. 2010). For example, for RHOA, an increase in ENaC subunit insertion into the plasma membrane through effects on microtubule was reported (Pochynyuk et al. 2006, 2007). For RAC-1, which also enhances ENaC activity, an upregulation of MR nuclear translocation and transcriptional activity was demonstrated and even a ligand independent activation of the MR was shown (Staruschenko et al. 2004, Shibata et al. 2008, Pavlov et al. 2004). Activation and enhanced expression of KRasA in renal cells by aldosterone furthermore led to an increased open probability of $\mathrm{ENaC}$ via the PI3K signaling cascade (Staruschenko et al. 2004). Furthermore, Blazer-Yost and coworkers and $\mathrm{Yu}$ and coworkers (Blazer-Yost et al. 1997, Yu et al. 2013) show that aldosterone also influences epigenetic regulation by promoter methylation and by histone modification, which may both be important for ENaC expression (Zhang et al. 2006, 2007). Enhanced nongenomic aldosterone-induced ENaC activity was also reported to rely on channel methylation (Stockand et al. 2000, Zhou \& Bubien 2001). In summary, aldosterone-induced sodium reabsorption by $\mathrm{ENaC}$ has genomic and nongenomic elements. Besides facilitating genomic effects, nongenomic effects can also be involved in regulatory feedback loops, as can be seen for $\mathrm{ENaC}$ activity which can be decreased by enhanced nongenomic MR-MAP kinase activation (Booth \& Stockand 2003, Grossmann et al. 2004).

$\boldsymbol{N a} \boldsymbol{a}^{+}-K^{+}-\boldsymbol{A T P a} \boldsymbol{e}$ In the collecting tubule early effects of aldosterone on $\mathrm{Na}^{+-} \mathrm{K}^{+}$-ATPase activity have been described in adrenalectomized animals but are controversial (Doucet \& Katz 1981, El Mernissi \& Doucet 1984, Fujii et al. 1990). Discrepancies in reports may result from indirect effects of other transporters on $\mathrm{Na}^{+-} \mathrm{K}^{+}-$ATPase pump activity or from different isoforms expressed in different models and tissues (Summa et al. 2004). Again just like for $\mathrm{ENaC}$, $\mathrm{Na}^{+}-\mathrm{K}^{+}$-ATPase response to aldosterone seems to involve trafficking of preexisting subunits to the membrane as well as de novo synthesis (El Mernissi \& Doucet 1984, BlotChabaud et al. 1990, Kolla \& Litwack 2000, Summa et al. 2001, Musch et al. 2008). SGK, an MR target gene, and aldosterone were shown to stimulate long-term effects synergistically but independently (Alvarez de la Rosa et al. 2006).
๑) 2017 Society for Endocrinology Printed in Great Britain
Published by Bioscientifica Ltd. 
Aldosterone-induced trafficking of the $\mathrm{Na}^{+}-\mathrm{K}^{+}$-ATPase $\alpha$ and $\beta$ subunits to the basolateral membrane was dependent on PKD, suggesting a nongenomic mechanism (Dooley et al. 2013). Furthermore, activation of PKC was shown to be required for aldosterone-induced genomic increase in $\alpha 1-\mathrm{Na}^{+}-\mathrm{K}^{+}-\mathrm{ATPase}$ mRNA, thus functionally linking nongenomic to genomic effects (Le Moellic et al. 2004). Therefore, overall, $\mathrm{Na}^{+}-\mathrm{K}^{+}-$ATPase activity seems to facilitate chronic sodium reabsorption in the collecting duct mediated by genomic and modulated by nongenomic aldosterone signaling events. However, a rapid inhibitory component on $\mathrm{Na}^{+}-\mathrm{K}^{+}$-ATPase activity mediated by PKC in cardiomyocytes and vascular tissue was also described for aldosterone (Alzamora et al. 2003, Mihailidou et al. 2004).

NHE For both NHE1 and NHE3 rapid aldosteronedependent changes in signaling and ion transport activity have been reported. While NHE1 is expressed ubiquitously at the basal membrane of polarized tissues and also in unpolarized cells, NHE3 is expressed in apical membranes in the renal and intestinal tissues that are responsible for $\mathrm{Na}^{+}$absorption and proton secretion or rather $\mathrm{HCO}_{3}{ }^{-}$ absorption. A rapid stimulation of NHE1 has been one of the earliest and best investigated nongenomic effects described for aldosterone in different renal cell lines and was mediated for example by intracellular calcium and ERK1/2 phosphorylation in MTAL and MDCK-C11 cells (Gekle et al. 1996, 1998, 2001, Watts et al. 2006, Pinto et al. 2008). NHE1 is not only known for its effects on electrolyte and acid-base regulation but also for its function as a regulator of cytoskeletal function which affects various transport processes, cell motion and cell volume and perhaps also fibronectin synthesis (Markos et al. 2005, Leite-Dellova et al. 2008, Zhang et al. 2010, Braga-Sobrinho et al. 2012). Furthermore, NHE1 is also important for other organs like vasculature and heart (Ebata et al. 1999, Michea et al. 2005, Miyata et al. 2005, Matsui et al. 2007, De Giusti et al. 2011) and a genomic increased NHE1 expression induced by aldosterone has been additionally described in various tissues (Karmazyn et al. 2001). In strips of human arteries, aldosterone-induced changes in intracellular $\mathrm{pH}$ mediated by NHE1 could be blocked by the MR antagonist RU28318 and could be mimicked by cortisol but only in the presence of an 11beta-hydroxysteroid dehydrogenase 2 inhibitor (Alzamora et al. 2000).

In the proximal tubule NHE3 activity and expression at the apical brush border, but not total NHE3 expression, were aldosterone sensitive, suggesting an increase in trafficking to the plasma membrane. Although the effect is persistent and lasting over several days, the involvement of the EGFR signaling pathways indicates a possible nongenomic mechanism (Krug et al. 2003, Drumm et al. 2006). Furthermore, it has been demonstrated that NHE3 expression is increased via SGK1 and genomic effects on the long-term (Musch et al. 2008). Conversely, aldosterone inhibited maximal velocity of NHE3 via ERK1/2 in MTAL, thus reducing bicarbonate reabsorption (Good et al. 2006, Watts et al. 2006). It was postulated that by counteracting the overall proton excreting effect of aldosterone, the kidney is enabled to regulate $\mathrm{Na}^{+}$balance and volume while maintaining acid-base balance (Good et al. 2002).

$\boldsymbol{H}^{+}$-ATPase Aldosterone is involved in acid-base homeostasis not only through NHE but also through nongenomic regulation of electrogenic vacuolar type $\mathrm{H}^{+}$-ATPase. Enhanced proton secretion is achieved rapidly within $15 \mathrm{~min}$ and most probably by influencing microtubule and PKC-dependent rapid trafficking of the pumps to the cell membrane (Gekle et al. 1997, Winter et al. 2004, Dos Santos et al. 2009). These effects not only occur in kidney but also in other organs (Ehrenfeld et al. 1985, Harvey 1992, Roy et al. 2013). Again the effects of aldosterone on $\mathrm{H}^{+}$-ATPase seem to combine rapid nongenomic and genomic effects as it has been shown in proximal renal tubule (Leite-Dellova et al. 2011).

Overall, nongenomic aldosterone signaling in the kidney seems to facilitate genomic signaling by rapidly activating transporters either by inhibiting their degradation or by enhancing their surface expression through facilitating intracellular trafficking.

\section{Nongenomic effects in the cardiovascular system}

After exploring physiological MR function in kidney and other epithelial target tissues, the cardiovascular system was identified as a main target for pathological MR actions (Brilla \& Weber 1992, Brilla et al. 1994, Young et al. 1994). The importance of the MR for eliciting pathological effects was impressively shown by several clinical trials including RALES, EPHESUS, EMPHASIS-HF, TOPCAT and the $4 \mathrm{E}$ study, in which MR antagonists were used in patients with cardiovascular diseases (Pitt et al. 1999, 2003a,b, 2014, Zannad et al. 2010). New genomic target genes were identified that support pathological effects, including PAI-1, CTGF, PGF and EGFR. In animal models, activated MR was shown to increase endothelial dysfunction,

Published by Bioscientifica Ltd. 
oxidative stress, inflammation and tissue remodeling. Consequently, nongenomic aldosterone effects were extensively studied as modulators of pathological effects in cardiovascular tissues and cells.

Vascular smooth muscle cells In VSMCs nongenomic aldosterone signaling has been demonstrated to lead to vasoconstriction, although the underlying signaling pathways are complex and they include ERK phosphorylation, intracellular calcium, cAMP and NHE, PLC, IGF1 and c-SRC, PI3K and PDGFR (Wehling et al. 1994, Christ et al. 1995, Ebata et al. 1999, Manegold et al. 1999, Michea et al. 2005, Yamada et al. 2008, Gros et al. 2011) (Fig. 3). Enhanced vasoconstriction may also include PKC and L- or T-type calcium channels in the glomerular microcirculation (Arima et al. 2003) and can be mediated by enhanced ROS production via c-SRC and p38 (Callera et al. 2005a,b). As described above, a crosstalk with receptor tyrosine kinases like EGFR, IGF1R and PDGFR and their transactivation seem to be a common theme as well as a crosstalk with GPCRs, especially AT1 and GPER1 (Mazak et al. 2004, Gros et al. 2011). Aldosterone also impairs guanylyl cyclase activity by cysteinyl thiol oxidation in VSMCs, which enhances vascular contractility (Maron et al. 2009).

Endothelial cells In endothelial cells NO production can be rapidly stimulated by aldosterone through enhanced NO synthase activity and phosphorylation mediated by PI3K (Liu et al. 2003, Uhrenholt et al. 2003, Mutoh et al. 2008). This can somewhat counteract the overall vasoconstrictor effect of aldosterone in vessels via PLC and IP3 which usually prevails (Arima et al. 2004). On the other hand aldosterone can enhance ROS availability in endothelial cells, for example, by activating NADPH oxidase via c-SRC and RAC-1 (Iwashima et al. 2008) or by reducing G6PD activity and GSH levels (Leopold et al. 2007). This can decrease overall NO bioavailability by peroxynitrite formation or uncoupling of eNOS by eNOS cofactor depletion, which will lead to preferential ROS and not NO production (Landmesser et al. 2003, Thomas et al. 2006). Furthermore, enhanced ROS production can also inhibit eNOS itself (Sanz-Rosa et al. 2005, Nagata et al. 2006). By increasing ENaC insertion into the plasma membrane aldosterone via MR can also increase cellular volume and stiffness, a state associated with decreased formation of NO. This observation provides a comprehensive link between high salt and hypertension but also between inflammation and vascular injury, because C-reactive protein, an acute phase protein of inflammation, has been shown to enhance this process (Kusche-Vihrog et al. 2008, 2011, Fels et al. 2010). Also regulation of local vasoconstrictors like endothelin-1 and angII are mediated by aldosterone and may be of relevance for endothelial function (Lariviere et al. 1993, Sugiyama et al. 2005).

Vessels Not surprisingly, in clinical studies with healthy individuals, rapid aldosterone actions on the vasculature seem to depend on the adrenergic and health status of the individuals. Infusion of aldosterone usually leads to a rapid increase in vascular resistance and a decrease in

Proliferation (DNA synthesis)

Cell growth/apoptosis

Migration/adhesion

Senescence

Contraction

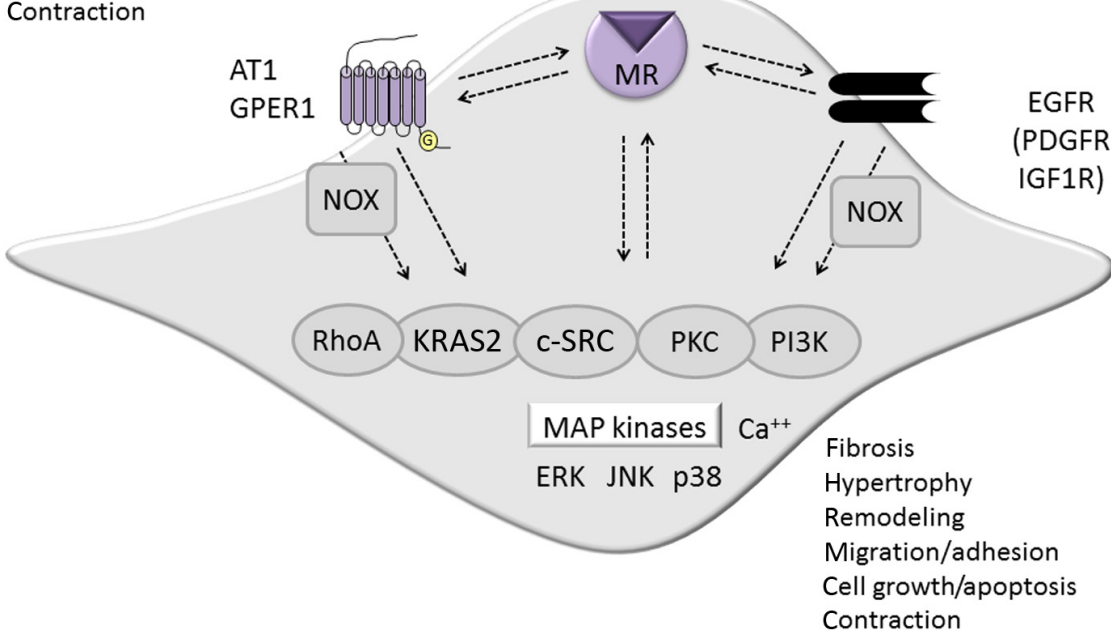

\section{Figure 3}

Components of rapid aldosterone signaling in VSMCs. Vascular smooth muscle cells (VSMCs) are one of the best studied models for nongenomic MR signaling pathways. As common interaction partners of the MR, GPCR like AT1 and GPER1 as well as receptor tyrosine kinases like EGFR, PDGFR and IGF1R have been identified at the membrane. In the cytosol, rapid MR signaling influences not only ROS homeostasis and the activity of different signaling molecules like small GTPases like RhoA and KRas but also kinases like c-src, PKC, PI3K, MAP kinases (including ERK, JNK and p38) and $\mathrm{Ca}^{++}$signaling.
๑) 2017 Society for Endocrinology Printed in Great Britain 
forearm blood flow within the first $10 \mathrm{~min}$ after infusion (Wehling et al. 1998, Schmidt et al. 1999, 2001, 2003, Romagni et al. 2003, Gunaruwan et al. 2005). After inhibiting NO synthase, enhanced vasoconstriction was reported (Schmidt et al. 2006, Nietlispach et al. 2007), suggesting that a rapid vasodilation occurs via NO synthesis in the endothelium while vasoconstriction is mediated by vascular smooth muscle cells. Also renal plasma flow was reduced after aldosterone infusion if the effect of the endothelium is excluded by simultaneous application of L-NMMA to inhibit NO synthase (Schmidt et al. 2006). Likewise, Hwang and coworkers show that in healthy older people, acute MR antagonism impairs endothelial function by inhibiting NO formation and endotheliumdependent vasorelaxation (Hwang et al. 2016). This fits well to observations made by Liu and coworkers and confirmed by Heylen and coworkers who showed that acute aldosterone application can lead to a vasodilation dependent on NO generation from the endothelium and to vasoconstriction via ROS in endothelium-denuded vessels (Liu et al. 2003, Heylen et al. 2009). Consequently, in mouse mesenteric vessels and endotheliumdenuded rings, aldosterone rapidly leads to enhanced vasoconstriction (Yamada et al. 2008, Gros et al. 2011).

In conclusion, nongenomic aldosterone signaling in VSMCs seems to lead to increased ROS formation, tyrosine kinase receptor activation, GPCR activation and supports overall vasoconstriction which aggravates pathological MR effects in vessels and supports genomic effects. In endothelial cells, aldosterone can rapidly activate or inactivate eNOS and NO depending on cell context, which again mainly seems to facilitate pathological MR effects but may also be part of a regulatory feedback loop. In addition, orthostasis is known to induce rapid aldosterone secretion, which may play a role in rapid hemodynamic adaptation to changes in posture by inducing vasoconstriction as a physiological response.

Heart The detrimental effects of aldosterone/ MR in the heart mimic those of the vasculature and include inflammation, fibrosis, cardiac hypertrophy and electrical remodeling. In ischemia-reperfusion experiments of the heart, aldosterone and low concentrations of cortisol both led to comparable exacerbation of damage via the MR (Mihailidou et al. 2009). Genomically, proinflammatory genes like ICAM-1, VCAM-1, PAI-1 and SPP-1 and osteopontin are upregulated by aldosterone/MR in addition to profibrotic genes for collagen I and III, CTGF and PGF
(Nguyen Dinh Cat \& Jaisser 2012). These genomic effects again seem to be supported and enhanced by nongenomic effects. One important mediator in this seems to be the generation of ROS through enhanced NOX activation and possible G6PD decrease. A rapid aldosterone-dependent increase in nongenomically generated ROS by NOX activation followed by myocyte apoptosis and ASK1 activation was demonstrated by Hayashi and coworkers in neonatal cardiomyocytes, and in adult ventricular cardiomyocytes, enhanced ROS production led to ERK1/2 activation and increased MMP-2 and MMP-9 activity (Rude et al. 2005, Hayashi et al. 2008).

A rapid increase in contractility was detected by some groups after aldosterone treatment in rat isolated working heart (Moreau et al. 1996, Barbato et al. 2002) while other groups found no effect on contractility or a reduced contractility in human trabeculae (Chai et al. 2005, Matsui et al. 2007). During ischemia, nongenomic aldosterone effects reduce coronary blood flow and thereby impair cardiac metabolic and contractile function (Fujita et al. 2005). Aldosterone/MR can also directly stimulate hypertrophy in neonatal rat ventricular myocytes through the activation of ERK, JNK and PKC $\alpha$ (Okoshi et al. 2004). Additionally, aldosterone via PKC $\varepsilon$ leads to a rapid but prolonged activation of $\mathrm{Na}^{+} \mathrm{K}^{+} 2 \mathrm{Cl}^{-}$ cotransporter and a decrease in $\mathrm{Na}^{+}-\mathrm{K}^{+}-\mathrm{ATPase}$ activity, which supports myocyte hypertrophy (Mihailidou et al. 1998, 2000, 2002, 2004). Increased intracellular sodium may then affect calcium content and thereby contractile status of cardiomyocytes. Sodium influx is also enhanced by NHE1 activation via EGFR and ROS (Matsui et al. 2007, De Giusti et al. 2011) and may lead to cell swelling. Changes in intracellular $\mathrm{pH}$ mediated by changes in NHE1 or sodium bicarbonate cotransporter activity may also account for increased myofilament responsiveness to calcium and thereby modulated contractility (Barbato et al. 2004, De Giusti et al. 2015). Furthermore, cardiac injury, i.e. perivascular and interstitial fibrosis and hypertrophy, induced by DOCA can be reduced by NHE1 blockade (Fujisawa et al. 2003, Young \& Funder 2003). Aldosterone also increases monophasic action potential duration within minutes after intravenous application which may support the development of arrhythmias (Tillmann et al. 2002). In HL-1 cells, aldosterone activates p38 to induce cardiotropin-1 expression, a cytokine with hypertrophic effects on cardiomyocytes (LopezAndres et al. 2008). Similarly, p38 activation is required for aldosterone-induced Ctgf gene expression in ventricular
Published by Bioscientifica Ltd 
cardiomyocytes (Lee et al. 2004). In both cases nongenomic pathways regulate genomic effects.

In cardiac fibroblasts, aldosterone can stimulate collagen-I-deposition and elastogenesis via Galpha13, C-SRC and IGF1R signaling (Bunda et al. 2007, 2009). In neonatal cardiac fibroblasts aldosterone favors cell cycle progression and cell proliferation mediated by AT1 via ERK1/2 activation which enhances the expression of cyclins D1 and E2 (Wang et al. 2013). Again nongenomic and genomic pathways are closely intertwined and seem to be of pathophysiological relevance.

Taken together, the role of nongenomic MR effects has been best characterized in classical epithelial MR target organs like kidney and colon and in the cardiovascular system for modulating physiological and pathological processes. However, nongenomic MR effects have been also well studied in the brain (Joels et al. 2012) and are becoming increasingly important in other tissues of pathological relevance like adipose tissue and immune cells (Vecchiola et al. 2016).

\section{Conclusions}

In summary, the existence of nongenomic aldosterone signaling has been well established and many of the signaling components have been identified. The involvement of the classical MR in many of the nongenomic signaling effects has been proven, although an additional membrane receptor may exist. A possible candidate for such a receptor is GPER1 but further investigations for this are required. Crosstalk between nongenomic aldosterone signaling and other signaling pathways has been demonstrated including signaling of receptor tyrosine kinases like EGFR, PDGFR and IGF1R and also GPCRs like AT1 and GPER1. Nongenomic aldosterone signaling occurs in various tissues including epithelial tissues like kidney and colon and nonepithelial tissues like heart, vasculature and brain. Most data are available for kidney and cardiovascular tissue, where the rapid effects seem to support physiological and pathophysiological genomic effects of aldosterone and MR or may be involved in regulatory loops. Because of the close interaction between genomic and nongenomic effects, nongenomic aldosterone signaling can also lead to long lasting and persistent effects. They also may provide new targets for modulation of pathophysiological aldosterone/MR actions.
Declaration of interest

The authors declare that there is no conflict of interest that could be perceived as prejudicing the impartiality of this review.

\section{Funding}

The authors were supported by the EU COST action ADMIRE 1301 and the RTG 2155 ProMoAge.

\section{References}

Alvarez de la Rosa D, Gimenez I, Forbush B \& Canessa CM 2006 SGK1 activates $\mathrm{Na}+-\mathrm{K}+-\mathrm{ATPa}$ in amphibian renal epithelial cells. American Journal of Physiology: Cell Physiology 290 C492-C498. (doi:10.1152/ ajpcell.00556.2004)

Alzamora R, Michea L \& Marusic ET 2000 Role of 11beta-hydroxysteroid dehydrogenase in nongenomic aldosterone effects in human arteries. Hypertension 35 1099-1104. (doi:10.1161/01.HYP.35.5.1099)

Alzamora R, Marusic ET, Gonzalez M \& Michea L 2003 Nongenomic effect of aldosterone on $\mathrm{Na}+, \mathrm{K}+$-adenosine triphosphatase in arterial vessels. Endocrinology 144 1266-1272. (doi:10.1210/en.2002-220950)

Arima S, Kohagura K, Xu HL, Sugawara A, Abe T, Satoh F, Takeuchi K \& Ito S 2003 Nongenomic vascular action of aldosterone in the glomerular microcirculation. Journal of the American Society of Nephrology 14 2255-2263. (doi:10.1097/01. ASN.0000083982.74108.54)

Arima S, Kohagura K, Xu HL, Sugawara A, Uruno A, Satoh F, Takeuchi K \& Ito S 2004 Endothelium-derived nitric oxide modulates vascular action of aldosterone in renal arteriole. Hypertension 43 352-357. (doi:10.1161/01.HYP.0000111138.78714.1a)

Arriza JL, Weinberger C, Cerelli G, Glaser TM, Handelin BL, Housman DE \& Evans RM 1987 Cloning of human mineralocorticoid receptor complementary DNA: structural and functional kinship with the glucocorticoid receptor. Science 237 268-275. (doi:10.1126/ science.3037703)

Ashton AW, Le TYL, Gomez-Sanchez CE, Morel-Kopp MC, McWhinney B, Hudson A \& Mihailidou AS 2015 Role of nongenomic signaling pathways activated by aldosterone during cardiac reperfusion injury. Molecular Endocrinology 29 1144-1155. (doi:10.1210/ME.2014-1410)

Barbato JC, Mulrow PJ, Shapiro JI \& Franco-Saenz R 2002 Rapid effects of aldosterone and spironolactone in the isolated working rat heart. Hypertension 40 130-135. (doi:10.1161/01.HYP.0000025879.29822.24)

Barbato JC, Rashid S, Mulrow PJ, Shapiro JI \& Franco-Saenz R 2004 Mechanisms for aldosterone and spironolactone-induced positive inotropic actions in the rat heart. Hypertension $\mathbf{4 4} 751$. (doi:10.1161/01.HYP.0000144466.11568.7e)

Barton M \& Prossnitz ER 2015 Emerging roles of GPER in diabetes and atherosclerosis. Trends in Endocrinology and Metabolism 26 185-192. (doi:10.1016/j.tem.2015.02.003)

Batenburg WW, Jansen PM, van den Bogaerdt AJ \& Danser J 2012 Angiotensin II-aldosterone interaction in human coronary microarteries involves GPR30, EGFR, and endothelial NO synthase. Cardiovascular Research 94 136. (doi:10.1093/cvr/cvs016)

Baudrand R, Gupta N, Garza AE, Vaidya A, Leopold JA, Hopkins PN, Jeunemaitre X, Ferri C, Romero JR, Williams J, et al. 2016 Caveolin 1 modulates aldosterone-mediated pathways of glucose and lipid homeostasis. Journal of the American Heart Association: Cardiovascular and Cerebrovascular Disease 5 e003845. (doi:10.1161/ JAHA.116.003845)

Bernelot Moens SJ, Schnitzler GR, Nickerson M, Guo H, Ueda K, Lu Q, Aronovitz MJ, Nickerson H, Baur WE, Hansen U, et al. 2012 Rapid
๑ 2017 Society for Endocrinology Printed in Great Britain 
estrogen receptor signaling is essential for the protective effects of estrogen against vascular injury. Circulation 126 1993. (doi:10.1161/ CIRCULATIONAHA.112.124529)

Blazer-Yost BL, Hughes CL \& Nolan PL 1997 Protein prenylation is required for aldosterone-stimulated $\mathrm{Na}+$ transport. American Journal of Physiology 272 C1928-C1935.

Blot-Chabaud M, Wanstok F, Bonvalet JP \& Farman N 1990 Cell sodiuminduced recruitment of $\mathrm{Na}(+)-\mathrm{K}(+)$-ATPase pumps in rabbit cortical collecting tubules is aldosterone-dependent. Journal of Biological Chemistry 265 11676-11681.

Booth RE \& Stockand JD 2003 Targeted degradation of ENaC in response to PKC activation of the ERK1/2 cascade. American Journal of Physiology: Renal Physiology 284 F938-F947. (doi:10.1152/ ajprenal.00373.2002)

Braga-Sobrinho C, Leite-Dellova DCA \& Mello-Aires M 2012 Action of ANP on the nongenomic dose-dependent biphasic effect of aldosterone on NHE1 in proximal S3 segment. Journal of Steroid Biochemistry and Molecular Biology 128 89-97. (doi:10.1016/j. jsbmb.2011.11.011)

Brailoiu GC, Benamar K, Arterburn JB, Gao E, Rabinowitz JE, Koch WJ \& Brailoiu E 2013 Aldosterone increases cardiac vagal tone via G protein-coupled oestrogen receptor activation. Journal of Physiology 591 4223-4235. (doi:10.1113/jphysiol.2013.257204)

Brilla CG \& Weber KT 1992 Mineralocorticoid excess, dietary sodium and myocardial fibrosis. Journal of Laboratory and Clinical Medicine $\mathbf{1 2 0}$ 893-901.

Brilla CG, Zhou G, Matsubara L \& Weber KT 1994 Collagen metabolism in cultured adult rat cardiac fibroblasts: response to angiotensin II and aldosterone. Journal of Molecular and Cellular Cardiology 26 809-820. (doi:10.1006/jmcc.1994.1098)

Bunda S, Liu P, Wang Y, Liu K \& Hinek A 2007 Aldosterone induces elastin production in cardiac fibroblasts through activation of insulin-like growth factor-I receptors in a mineralocorticoid receptorindependent manner. American Journal of Pathology 171 809-819. (doi:10.2353/ajpath.2007.070101)

Bunda S, Wang Y, Mitts TF, Liu P, Arab S, Arabkhari M \& Hinek A 2009 Aldosterone stimulates elastogenesis in cardiac fibroblasts via mineralocorticoid receptor-independent action involving the consecutive activation of Galpha(13), c-Src, the insulin-like growth factor-I receptor, and phosphatidylinositol 3-kinase/Akt. Journal of Biological Chemistry 284 16633-16647. (doi:10.1074/jbc. M109.008748)

Callera GE, Montezano ACI, Yogi A, Tostes RC, He Y, Schiffrin EL \& Touyz RM 2005 a c-Src-dependent nongenomic signaling responses to aldosterone are increased in vascular myocytes from spontaneously hypertensive rats. Hypertension 46 1032-1038. (doi:10.1161/01. HYP.0000176588.51027.35)

Callera GE, Touyz RM, Tostes RC, Yogi A, He Y, Malkinson S \& Schiffrin EL $2005 b$ Aldosterone activates vascular p38MAP kinase and NADPH oxidase via c-Src. Hypertension 45 773-779. (doi:10.1161/01. HYP.0000154365.30593.d3)

Callera GE, Yogi A, Briones AM, Montezano ACI, He Y, Tostes RCA, Schiffrin EL \& Touyz RM 2011 Vascular proinflammatory responses by aldosterone are mediated via c-Src trafficking to cholesterolrich microdomains: role of PDGFR. Cardiovascular Research 91720. (doi:10.1093/cvr/cvr131)

Cannavo A, Liccardo D, Eguchi A, Elliott KJ, Traynham CJ, Ibetti J, Eguchi S, Leosco D, Ferrara N, Rengo G, et al. 2016 Myocardial pathology induced by aldosterone is dependent on non-canonical activities of G protein-coupled receptor kinases. Nature Communications 710877. (doi:10.1038/ncomms10877)

Cascella T, Radhakrishnan Y, Maile LA, Busby WH, Gollahon K, Colao A \& Clemmons DR 2010 Aldosterone enhances IGF-I-mediated signaling and biological function in vascular smooth muscle cells Endocrinology 151 5851-5864. (doi:10.1210/en.2010-0350)
Chai W, Garrelds IM, Vries Rd, Batenburg WW, van Kats JP \& Danser AHJ 2005 Nongenomic effects of aldosterone in the human heart. Interaction with angiotensin II. Hypertension 46 701-706. (doi:10.1161/01.HYP.0000182661.98259.4f)

Chen D, Chen Z, Park C, Centrella M, McCarthy T, Chen L, Al-Omari A \& Moeckel GW 2013 Aldosterone stimulates fibronectin synthesis in renal fibroblasts through mineralocorticoid receptor-dependent and independent mechanisms. Gene 531 23-30. (doi:10.1016/j. gene.2013.08.047)

Cheng SB, Dong J, Pang Y, LaRocca J, Hixon M, Thomas P \& Filardo EJ 2014 Anatomical location and redistribution of $G$ protein-coupled estrogen receptor-1 during the estrus cycle in mouse kidney and specific binding to estrogens but not aldosterone. Molecular and Cellular Endocrinology 382 950-959. (doi:10.1016/j.mce.2013.11.005)

Christ M, Sippel K, Eisen C \& Wehling M 1994 Non-classical receptors for aldosterone in plasma membranes from pig kidneys. Molecular and Cellular Endocrinology 99 R31-R34. (doi:10.1016/03037207(94)90027-2)

Christ M, Meyer C, Sippel K \& Wehling M 1995 Rapid aldosterone signaling in vascular smooth muscle cells: involvement of phospholipase C, diacylglycerol and protein kinase C a. Biochemical and Biophysical Research Communications 213 123-129. (doi:10.1006/ bbrc.1995.2106)

Clever U \& Karlson P 1960 Induction of puff changes in the salivary gland chromosomes of Chironomus tentans by ecdysone. Experimental Cell Research 20 623-626. (doi:10.1016/00144827(60)90141-5)

Coutinho P, Vega C, Pojoga LH, Rivera A, Prado GN, Yao TM, Adler G, Torres-Grajales M, Maldonado ER, Ramos-Rivera A, et al. 2014 Aldosterone's rapid, nongenomic effects are mediated by striatin: a modulator of aldosterone's effect on estrogen action. Endocrinology 155 2233-2243. (doi:10.1210/en.2013-1834)

De Giusti VC, Nolly MB, Yeves AM, Caldiz CI, Villa-Abrille MaC, Chiappe de Cingolani GE, Ennis IL, Cingolani HE \& Aiello EA 2011 Aldosterone stimulates the cardiac $\mathrm{Na}+\mathrm{H}+$ exchanger via transactivation of the epidermal growth factor receptor. Hypertension 58 912. (doi:10.1161/HYPERTENSIONAHA.111.176024)

De Giusti VC, Orlowski A, Ciancio MC, Espejo MS, Gonano LA, Caldiz CI, Vila Petroff MG, Villa-Abrille MC \& Aiello EA 2015 Aldosterone stimulates the cardiac sodium/bicarbonate cotransporter via activation of the g protein-coupled receptor gpr30. Journal of Molecular and Cellular Cardiology 89 260-267. (doi:10.1016/j. yjmcc.2015.10.024)

Dooley R, Angibaud E, Yusef YR, Thomas W \& Harvey BJ 2013 Aldosterone-induced $\mathrm{ENaC}$ and basal $\mathrm{Na}+/ \mathrm{K}+$-ATPase trafficking via protein kinase D1-phosphatidylinositol 4-kinaseIII+' trans Golgi signalling in M1 cortical collecting duct cells. Molecular and Cellular Endocrinology 372 86-95. (doi:10.1016/j.mce.2013.03.011)

Dorrance AM, Osborn HL, Grekin R \& Webb RC 2001 Spironolactone reduces cerebral infarct size and EGF-receptor mRNA in strokeprone rats. American Journal of Physiology: Regulatory, Integrative and Comparative Physiology 281 R944-R950.

Dos Santos PMC, Freitas FP, Mendes J, Tararthuch AL \& Fernandez R 2009 Differential regulation of H+-ATPases in MDCK-C11 cells by aldosterone and vasopressin. Canadian Journal of Physiology and Pharmacology 87 653-665. (doi:10.1139/Y09-057)

Doucet A \& Katz A 1981 Short-term effect of aldosterone on Na-K-ATPase in single nephron segments. American Journal of Physiology $\mathbf{2 4 1}$ F273-F278.

Drumm K, Kress TR, Gassner B, Krug AW \& Gekle M 2006 Aldosterone stimulates activity and surface expression of NHE3 in human primary proximal tubule epithelial cells (RPTEC). Cellular Physiology and Biochemistry 17 21-28. (doi:10.1159/000091456)

Ebata S, Muto S, Okada K, Nemoto J, Amemiya M, Saito T \& Asano Y 1999 Aldosterone activates $\mathrm{Na}+\mathrm{H}+$ exchange in vascular smooth http://joe.endocrinology-journals.org

DOI: 10.1530/JOE-16-0659
() 2017 Society for Endocrinology Printed in Great Britain
Published by Bioscientifica Ltd. 
muscle cells by nongenomic and genomic mechanisms. Kidney International 56 1400-1412. (doi:10.1046/j.1523-1755.1999.00674.x)

Ehrenfeld J, Garcia-Romeu F \& Harvey BJ 1985 Electrogenic active proton pump in Rana esculenta skin and its role in sodium ion transport. Journal of Physiology 359 331-355. (doi:10.1113/jphysiol.1985. sp015588)

Eisen C, Meyer C, Christ M, Theisen K \& Wehling M 1994 Novel membrane receptors for aldosterone in human lymphocytes: a $50 \mathrm{kDa}$ protein on SDS-PAGE. Cellular and Molecular Biology 40 351-358.

El Mernissi G \& Doucet A 1984 Short-term effect of aldosterone on renal sodium transport and tubular Na-K-ATPase in the rat. Pflügers Archiv: European Journal of Physiology 399 139-146. (doi:10.1007/ bf00663910)

Fazal L, Azibani F, Bihry N, Coutance G, Polidano E, Merval R, Vodovar N, Launay JM, Delcayre C \& Samuel JL 2014 Akt-mediated cardioprotective effects of aldosterone in type 2 diabetic mice. FASEB Journal 28 2430-2440. (doi:10.1096/fj.13-239822)

Feldman RD, Ding Q, Hussain Y, Limbird LE, Pickering JG \& Gros R 2016 Aldosterone mediates metastatic spread of renal cancer via the $\mathrm{G}$ protein coupled estrogen receptor (GPER). FASEB Journal 30 2086-2096. (doi:10.1096/fj.15-275552)

Fels J, Callies C, Kusche-Vihrog K \& Oberleithner H 2010 Nitric oxide release follows endothelial nanomechanics and not vice versa. Pflügers Archiv: European Journal of Physiology 460 915-923.

Ferreira NS, Cau SBA, Silva MAB, Manzato CP, Mestriner FoLAC, Matsumoto T, Carneiro FS \& Tostes RC 2015 Diabetes impairs the vascular effects of aldosterone mediated by $\mathrm{G}$ protein-coupled estrogen receptor activation. Frontiers in Pharmacology 634.

Fiebeler A, Schmidt F, Muller DN, Park JK, Dechend R, Bieringer M, Shagdarsuren E, Breu V, Haller H \& Luft FC 2001 Mineralocorticoid receptor affects AP-1 and nuclear factor-kappab activation in angiotensin II-induced cardiac injury. Hypertension 37 787-793. (doi:10.1161/01.HYP.37.2.787)

Filardo EJ, Quinn JA, Bland KI \& Frackelton AR 2000 Estrogen-induced activation of Erk-1 and Erk-2 requires the g protein-coupled receptor homolog, GPR30, and occurs via trans-activation of the epidermal growth factor receptor through release of HB-EGF. Molecular Endocrinology 14 1649-1660. (doi:10.1210/mend.14.10.0532)

Filardo EJ, Quinn JA, Frackelton AR \& Bland KI 2002 Estrogen action via the G protein-coupled receptor, GPR30: stimulation of adenylyl cyclase and cAMP-mediated attenuation of the epidermal growth factor receptor-to-MAPK signaling axis. Molecular Endocrinology 16 70-84. (doi:10.1210/mend.16.1.0758)

Fujii Y, Takemoto F \& Katz A 1990 Early effects of aldosterone on Na-K pump in rat cortical collecting tubules. American Journal of Physiology 259 F40-F45.

Fujisawa G, Okada K, Muto S, Fujita N, Itabashi N, Kusano E \& Ishibashi $\mathrm{S} 2003 \mathrm{Na} / \mathrm{H}$ exchange isoform 1 is involved in mineralocorticoid/ salt-induced cardiac injury. Hypertension 41 493. (doi:10.1161/01. HYP.0000056769.73726.E5)

Fujita M, Minamino T, Asanuma H, Sanada S, Hirata A, Wakeno M, Myoishi M, Okuda H, Ogai A, Okada Ki, et al. 2005 Aldosterone nongenomically worsens ischemia via protein kinase C-dependent pathways in hypoperfused canine hearts. Hypertension 46 113-117. (doi:10.1161/01.HYP.0000171184.84077.80)

Funder JW 2005 The nongenomic actions of aldosterone. Endocrine Reviews 26 313-321. (doi:10.1210/er.2005-0004)

Ganong WF \& Mulrow PJ 1958 Rate of change in sodium and potassium excretion after injection of aldosterone into the aorta and renal artery of the dog. American Journal of Physiology 195 337-342.

Garza AE, Rariy CM, Sun B, Williams JS, Lasky-Su J, Baudrand R, Yao T, Moize B, Hafiz WM, Romero JR, et al. 2014 Variants in striatin gene are associated with salt-sensitive blood pressure in mice and humans. Hypertension 65 211. (doi:10.1161/HYPERTENSIONAHA.114.04233)
Gekle M, Golenhofen N, Oberleithner H \& Silbernagl S 1996 Rapid activation of $\mathrm{Na}^{+} / \mathrm{H}^{+}$-exchange by aldosterone in renal epithelial cells requires $\mathrm{Ca}^{2+}$ and stimulation of a plasma membrane proton conductance. PNAS 93 10500-10504. (doi:10.1073/pnas.93.19.10500)

Gekle M, Silbernagl S \& Oberleithner H 1997 The mineralocorticoid aldosterone activates a proton conductance in cultured kidney cells. American Journal of Physiology 273 C1673-C1678.

Gekle M, Silbernagl S \& Wünsch S 1998 Non-genomic action of the mineralocorticoid aldosterone on cytosolic sodium in cultured kidney cells. Journal of Physiology $\mathbf{5 1 1}$ 255-263. (doi:10.1111/j.14697793.1998.255bi.x)

Gekle M, Freudinger R, Mildenberger S, Schenk K, Marschitz I \& Schramek H 2001 Rapid activation of $\mathrm{Na}^{+} / \mathrm{H}^{+}$-exchange in MDCK-cells by aldosterone involves MAP-kinases ERK1/2. Pflügers Archiv: European Journal of Physiology 441 781-786. (doi:10.1007/s004240000507)

Gekle M, Freudinger R, Mildenberger S \& Silbernagl S 2002 Aldosterone interaction with epidermal growth factor receptor signaling in MDCK cells. American Journal of Physiology: Renal Physiology 282 F669-F679. (doi:10.1152/ajprenal.00159.2001)

Gekle M, Mildenberger S, Freudinger R \& Grossmann C 2007 Altered collagen homeostasis in human aortic smooth muscle cells (HAoSMCs) induced by aldosterone. Pflügers Archiv: European Journal of Physiology 454 403-413. (doi:10.1007/s00424-007-0211-9)

Good DW, George T \& Watts BA 2002 Aldosterone inhibits $\mathrm{HCO}_{3}{ }^{-}$ absorption via a nongenomic pathway in medullary thick ascending limb. American Journal of Physiology: Renal Physiology 283 F699. (doi:10.1152/ajprenal.00133.2002)

Good DW, George T \& Watts BA III 2006 Nongenomic regulation by aldosterone of the epithelial NHE3 Na+/H+ exchanger. American Journal of Physiology: Cell Physiology 290 C757-C763. (doi:10.1152/ ajpcell.00391.2005)

Gros R, Ding Q, Armstrong S, O’Neil C, Pickering JG \& Feldman RD 2007 Rapid effects of aldosterone on clonal human vascular smooth muscle cells. American Journal of Physiology: Cell Physiology 292 C788-C794. (doi:10.1152/ajpcell.00407.2006)

Gros R, Ding Q, Sklar LA, Prossnitz EE, Arterburn JB, Chorazyczewski J $\&$ Feldman RD 2011 GPR30 expression is required for the mineralocorticoid receptor-independent rapid vascular effects of aldosterone. Hypertension 57 442-451. (doi:10.1161/ HYPERTENSIONAHA.110.161653)

Gros R, Ding Q, Liu B, Chorazyczewski J \& Feldman RD 2013 Aldosterone mediates its rapid effects in vascular endothelial cells through GPER activation. American Journal of Physiology: Cell Physiology 304 C532. (doi:10.1152/ajpcell.00203.2012)

Grossmann C \& Gekle M 2009 New aspects of rapid aldosterone signaling. Molecular and Cellular Endocrinology 308 53-62. (doi:10.1016/j.mce.2009.02.005)

Grossmann C, Freudinger R, Mildenberger S, Krug AW \& Gekle M 2004 Evidence for epidermal growth factor receptor as negative-feedback control in aldosterone-induced $\mathrm{Na}^{+}$reabsorption. American Journal of Physiology: Renal Physiology 286 F1226.

Grossmann C, Benesic A, Krug AW, Freudinger R, Mildenberger S, Gassner B \& Gekle M 2005 Human mineralocorticoid receptor expression renders cells responsive for nongenotropic aldosterone actions. Molecular Endocrinology 19 1697-1710. (doi:10.1210/me.2004-0469)

Grossmann C, Freudinger R, Mildenberger S, Husse B \& Gekle M 2008 EF domains are sufficient for nongenomic mineralocorticoid receptor actions. Journal of Biological Chemistry 283 7109-7116. (doi:10.1074/ jbc.M708751200)

Grossmann C, Husse B, Mildenberger S, Schreier B, Schuman K \& Gekle M 2010 Colocalization of mineralocorticoid and EGF receptor at the plasma membrane. Biochimica et Biophysica Acta (BBA): Molecular Cell Research 1803 584-590. (doi:10.1016/j.bbamcr.2010.02.008)

Gunaruwan P, Schmitt M, Sharman J, Lee L, Struthers A \& Frenneaux M 2005 Effects of aldosterone on forearm vasculature in treated http://joe.endocrinology-journals.org

DOI: $10.1530 / J O E-16-0659$
๑) 2017 Society for Endocrinology Printed in Great Britain 
chronic heart failure. American Journal of Cardiology 95 412-414 (doi:10.1016/j.amjcard.2004.09.047)

Harvey BJ 1992 Energization of sodium absorption by the H(+)-ATPase pump in mitochondria-rich cells of frog skin. Journal of Experimental Biology 172289.

Haseroth K, Gerdes D, Berger S, Feuring M, Gunther A, Herbst C, Christ M \& Wehling M 1999 Rapid nongenomic effects of aldosterone in mineralocorticoid-receptor-knockout mice. Biochemical and Biophysical Research Communications 266 257-261. (doi:10.1006/bbrc.1999.1771)

Hayashi H, Kobara M, Abe MK, Tanaka N, Gouda E, Toba H, Yamada H, Tatsumi T, Nakata T \& Matsubara H 2008 Aldosterone nongenomically produces NADPH oxidase-dependent reactive oxygen species and induces myocyte apoptosis. Hypertension Research $\mathbf{3 1}$ 363-375. (doi:10.1291/hypres.31.363)

Heylen E, Huang A, Sun D \& Kaley G 2009 Nitric oxide-mediated dilation of arterioles to intraluminal administration of aldosterone. Journal of Cardiovascular Pharmacology 54 535-542. (doi:10.1097/ FJC.0b013e3181bfb00d)

Hirono Y, Yoshimoto T, Suzuki N, Sugiyama T, Sakurada M, Takai S, Kobayashi N, Shichiri M \& Hirata Y 2007 Angiotensin II receptor type 1-mediated vascular oxidative stress and proinflammatory gene expression in aldosterone-induced hypertension: the possible role of local renin-angiotensin system. Endocrinology 148 1688-1696. (doi:10.1210/en.2006-1157)

Holzman JL, Liu L, Duke BJ, Kemendy AE \& Eaton DC 2007 Transactivation of the IGF-1R by aldosterone. American Journal of Physiology: Renal Physiology 292 F1219.

Huang S, Zhang A, Ding G \& Chen R 2009 Aldosterone-induced mesangial cell proliferation is mediated by EGF receptor transactivation. American Journal of Physiology: Renal Physiology 296 F1323. (doi:10.1152/ajprenal.90428.2008)

Huang LL, Nikolic-Paterson DJ, Ma FY \& Tesch GH 2012 Aldosterone induces kidney fibroblast proliferation via activation of growth factor receptors and PI3K/MAPK signalling. Nephron Experimental Nephrology 120 e115-e122. (doi:10.1159/000339500)

Hwang J \& Pallas DC 2014 STRIPAK complexes: structure, biological function, and involvement in human diseases. International Journal of Biochemistry and Cell Biology 47 118-148. (doi:10.1016/j. biocel.2013.11.021)

Hwang MH, Yoo JK, Luttrell M, Kim HK, Meade TH, English M, Talcott S, Jaffe IZ \& Christou DD 2016 Acute effect of mineralocorticoid receptor antagonism on vascular function in healthy older adults. Experimental Gerontology 73 86-94. (doi:10.1016/j. exger.2015.11.017)

Igarashi J, Hashimoto T, Shoji K, Yoneda K, Tsukamoto I, Moriue T, Kubota Y \& Kosaka H 2013 Dexamethasone induces caveolin-1 in vascular endothelial cells: implications for attenuated responses to VEGF. American Journal of Physiology: Cell Physiology 304 C790. (doi:10.1152/ajpcell.00268.2012)

Iwashima F, Yoshimoto T, Minami I, Sakurada M, Hirono Y \& Hirata Y 2008 Aldosterone induces superoxide generation via Rac1 activation in endothelial cells. Endocrinology 149 1009-1014. (doi:10.1210/ en.2007-0864)

Jaffe IZ \& Mendelsohn ME 2005 Angiotensin II and aldosterone regulate gene transcription via functional mineralocortocoid receptors in human coronary artery smooth muscle cells. Circulation Research 96 643-650. (doi:10.1161/01.RES.0000159937.05502.d1)

Joels M, Sarabdjitsingh RA \& Karst H 2012 Unraveling the time domains of corticosteroid hormone influences on brain activity: rapid, slow, and chronic modes. Pharmacological Reviews 64 901. (doi:10.1124/ pr.112.005892)

Karmazyn M, Sostaric JV \& Gan XT 2001 The myocardial $\mathrm{Na}^{+}$/ $\mathrm{H}^{+}$exchanger: a potential therapeutic target for the prevention of myocardial ischaemic and reperfusion injury and attenuation of postinfarction heart failure. Drugs 61 375-389. (doi:10.2165/00003495-200161030-00006)
Karpushev AV, Ilatovskaya DV, Pavlov TS, Negulyaev YA \& Staruschenko A 2010 Intact cytoskeleton is required for small $\mathrm{g}$ protein dependent activation of the epithelial $\mathrm{Na}(+)$ channel. PLOS ONE 5 e8827. (doi:10.1371/journal.pone.0008827)

Klein K \& Henk W 1964 Klinisch-experimentelle untersuchung über den einfluss von aldosteron auf hämodynamik und gerinnung. Zeitschrift für Kreislaufforschung 52 40-53.

Kolla V \& Litwack G 2000 Transcriptional regulation of the human NA/K ATPase via the human mineralocorticoid receptor. Molecular and Cellular Biochemistry 204 35-40.

Krug AW, Papavassiliou F, Hopfer U, Ullrich KJ \& Gekle M 2003 Aldosterone stimulates surface expression of NHE3 in renal proximal brush borders. Pflügers Archiv: European Journal of Physiology 446 492-496. (doi:10.1007/s00424-003-1033-z)

Krug AW, Allenhofer L, Monticone R, Spinetti G, Gekle M, Wang M \& Lakatta EG 2010 Elevated mineralocorticoid receptor activity in aged rat vascular smooth muscle cells promotes a proinflammatory phenotype via extracellular signal-regulated kinase 1/2 mitogenactivated protein kinase and epidermal growth factor receptordependent pathways. Hypertension 55 1476-1483. (doi:10.1161/ HYPERTENSIONAHA.109.148783)

Kusche-Vihrog K, Sobczak K, Bangel N, Wilhelmi M, Nechyporuk-Zloy V, Schwab A, Schillers H \& Oberleithner H 2008 Aldosterone and amiloride alter ENaC abundance in vascular endothelium. Pflügers Archiv: European Journal of Physiology 455 849-857. (doi:10.1007/ s00424-007-0341-0)

Kusche-Vihrog K, Urbanova K, Blanque A, Wilhelmi M, Schillers H, Kliche K, Pavenstadt H, Brand E \& Oberleithner H 2011 C-reactive protein makes human endothelium stiff and tight. Hypertension $\mathbf{5 7}$ 231-237. (doi:10.1161/HYPERTENSIONAHA.110.163444)

Kushibiki M, Yamada M, Oikawa K, Tomita H, Osanai T \& Okumura K 2007 Aldosterone causes vasoconstriction in coronary arterioles of rats via angiotensin II type-1 receptor: influence of hypertension. European Journal of Pharmacology 572 182-188. (doi:10.1016/j. ejphar.2007.06.017)

Landmesser U, Dikalov S, Price SR, McCann L, Fukai T, Holland SM, Mitch WE \& Harrison DG 2003 Oxidation of tetrahydrobiopterin leads to uncoupling of endothelial cell nitric oxide synthase in hypertension. Journal of Clinical Investigation 111 1201-1209. (doi:10.1172/JCI200314172)

Lariviere R, Thibault G \& Schiffrin EL 1993 Increased endothelin-1 content in blood vessels of deoxycorticosterone acetate-salt hypertensive but not in spontaneously hypertensive rats. Hypertension 21 294. (doi:10.1161/01.HYP.21.3.294)

Le Moellic C, Ouvrard-Pascaud A, Capurro C, Cluzeaud F, Fay M, Jaisser F, Farman N \& Blot-Chabaud M 2004 Early nongenomic events in aldosterone action in renal collecting duct cells: PKCalpha activation, mineralocorticoid receptor phosphorylation, and cross-talk with the genomic response. Journal of the American Society of Nephrology $\mathbf{1 5}$ 1145-1160.

Lee YS, Kim JA, Kim KL, Jang HS, Kim JM, Lee JY, Shin IS, Lee JS, Suh W, Choi JH, et al. 2004 Aldosterone upregulates connective tissue growth factor gene expression via p38 MAPK pathway and mineralocorticoid receptor in ventricular myocytes. Journal of Korean Medical Science 19 805-811. (doi:10.3346/jkms.2004.19.6.805)

Leite-Dellova DCA, Oliveira-Souza M, Malnic G \& Mello-Aires M 2008 Genomic and nongenomic dose-dependent biphasic effect of aldosterone on $\mathrm{Na}+\mathrm{H}+$ exchanger in proximal $\mathrm{S} 3$ segment: role of cytosolic calcium. American Journal of Physiology: Renal Physiology 295 F1342. (doi:10.1152/ajprenal.00048.2008)

Leite-Dellova DCA, Malnic G \& Mello-Aires M 2011 Genomic and nongenomic stimulatory effect of aldosterone on H+-ATPase in proximal S3 segments. American Journal of Physiology: Renal Physiology 300 F682.

Lemarie C, Paradis P \& Schiffrin E 2008 New insights on signaling cascades induced by cross-talk between angiotensin II and 
aldosterone. Journal of Molecular Medicine 86 673-678. (doi:10.1007/ s00109-008-0323-5)

Leopold JA, Dam A, Maron BA, Scribner AW, Liao R, Handy DE, Stanton RC, Pitt B \& Loscalzo J 2007 Aldosterone impairs vascular reactivity by decreasing glucose-6-phosphate dehydrogenase activity. Nature Medicine 13 189-197. (doi:10.1038/nm1545)

Liang X, Butterworth MB, Peters KW \& Frizzell RA 2010 AS160 modulates aldosterone-stimulated epithelial sodium channel forward trafficking Molecular Biology of the Cell 21 2024-2033. (doi:10.1091/mbc.E10-010042)

Limor R, Kaplan M, Sharon O, Knoll E, Naidich M, Weisinger G, Keidar S \& Stern N 2009 Aldosterone up-regulates 12- and 15-lipoxygenase expression and LDL oxidation in human vascular smooth muscle cells. Journal of Cellular Biochemistry 108 1203-1210. (doi:10.1002/ jcb.22352)

Liu SL, Schmuck S, Chorazcyzewski JZ, Gros R \& Feldman RD 2003 Aldosterone regulates vascular reactivity: short-term effects mediated by phosphatidylinositol 3-kinase-dependent nitric oxide synthase activation. Circulation 108 2400-2406. (doi:10.1161/01. CIR.0000093188.53554.44)

Loffing J, Zecevic M, Feraille E, Kaissling B, Asher C, Rossier BC, Firestone GL, Pearce D \& Verrey F 2001 Aldosterone induces rapid apical translocation of ENaC in early portion of renal collecting system: possible role of SGK. American Journal of Physiology: Renal Physiology 280 F 675.

Lopez-Andres N, Inigo C, Gallego I, Diez J \& Fortuno MA 2008 Aldosterone induces cardiotrophin-1 expression in HL-1 adult cardiomyocytes. Endocrinology 149 4970-4978. (doi:10.1210/en.20080120)

Lu Q, Pallas DC, Surks HK, Baur WE, Mendelsohn ME \& Karas RH 2004 Striatin assembles a membrane signaling complex necessary for rapid, nongenomic activation of endothelial NO synthase by estrogen receptor alpha. PNAS 101 17126-17131. (doi:10.1073/ pnas.0407492101)

Manegold JC, Falkenstein E, Wehling M \& Christ M 1999 Rapid aldosterone effects on tyrosine phosphorylation in vascular smooth muscle cells. Cellular and Molecular Biology 45 805-813.

Markos F, Healy V \& Harvey BJ 2005 Aldosterone rapidly activates $\mathrm{Na}+$ / $\mathrm{H}+$ exchange in $\mathrm{M}-1$ cortical collecting duct cells via a PKC-MAPK pathway. Nephron Physiology 99 1-9. (doi:10.1159/000081796)

Maron BA, Zhang YY, Handy DE, Beuve A, Tang SS, Loscalzo J \& Leopold JA 2009 Aldosterone increases oxidant stress to impair guanylyl cyclase activity by cysteinyl thiol oxidation in vascular smooth muscle cells. Journal of Biological Chemistry 284 7665-7672. (doi:10.1074/jbc.M809460200)

Matsui S, Satoh H, Kawashima H, Nagasaka S, Niu CF, Urushida T, Katoh H, Watanabe Y \& Hayashi H 2007 Non-genomic effects of aldosterone on intracellular ion regulation and cell volume in rat ventricular myocytes. Canadian Journal of Physiology and Pharmacology $\mathbf{8 5}$ 264-273. (doi:10.1139/Y07-017)

Mazak I, Fiebeler A, Muller DN, Park JK, Shagdarsuren E, Lindschau C, Dechend R, Viedt C, Pilz B, Haller H, et al. 2004 Aldosterone potentiates angiotensin II-induced signaling in vascular smooth muscle cells. Circulation 109 2792-2800. (doi:10.1161/01. CIR.0000131860.80444.AB)

McEneaney V, Harvey BJ \& Thomas W 2007 Aldosterone rapidly activates protein kinase D via a mineralocorticoid receptor/EGFR trans-activation pathway in the M1 kidney CCD cell line. Journal of Steroid Biochemistry and Molecular Biology 107 180-190. (doi:10.1016/j. jsbmb.2007.03.043)

McEneaney V, Harvey BJ \& Thomas W 2008 Aldosterone regulates rapid trafficking of epithelial sodium channel subunits in renal cortical collecting duct cells via protein kinase D activation. Molecular Endocrinology 22 881-892. (doi:10.1210/me.2007-0225)

McEneaney V, Dooley R, Harvey BJ \& Thomas W 2010a Protein kinase D stabilizes aldosterone-induced ERK1/2 MAP kinase activation in

http://joe.endocrinology-journals.org

DOI: 10.1530/JOE-16-0659
(C) 2017 Society for Endocrinology Printed in Great Britain
M1 renal cortical collecting duct cells to promote cell proliferation. Journal of Steroid Biochemistry and Molecular Biology 118 18-28. (doi:10.1016/j.jsbmb.2009.09.014)

McEneaney V, Dooley R, Yusef YR, Keating N, Quinn U, Harvey BJ \& Thomas W $2010 b$ Protein kinase D1 modulates aldosterone-induced ENaC activity in a renal cortical collecting duct cell line. Molecular and Cellular Endocrinology 325 8-17. (doi:10.1016/j.mce.2010.04.019)

Meinel S, Ruhs S, Schumann K, Strätz N, Trenkmann K, Schreier B, Grosse I, Keilwagen J, Gekle M \& Grossmann C 2013 Mineralocorticoid receptor interaction with SP1 generates a new response element for pathophysiologically relevant gene expression. Nucleic Acids Research 41 8045-8060. (doi:10.1093/nar/gkt581)

Meyer MR, Fredette NC, Daniel C, Sharma G, Amann K, Arterburn JB, Barton M \& Prossnitz ER 2016 Obligatory role for GPER in cardiovascular aging and disease. Science Signaling 9 ra105. (doi:10.1126/scisignal.aag0240)

Michea L, Delpiano AM, Hitschfeld C, Lobos L, Lavandero S \& Marusic ET 2005 Eplerenone blocks nongenomic effects of aldosterone on the $\mathrm{Na}+/ \mathrm{H}+$ exchanger, intracellular $\mathrm{Ca} 2+$ levels, and vasoconstriction in mesenteric resistance vessels. Endocrinology 146 973-980. (doi:10.1210/en.2004-1130)

Mihailidou AS \& Funder JW 2005 Nongenomic effects of mineralocorticoid receptor activation in the cardiovascular system. Steroids 70 347-351. (doi:10.1016/j.steroids.2005.02.004)

Mihailidou AS, Buhagiar KA \& Rasmussen HH $1998 \mathrm{Na}^{+}$influx and $\mathrm{Na}^{+-}$ $\mathrm{K}^{+}$pump activation during short-term exposure of cardiac myocytes to aldosterone. American Journal of Physiology 274 C175-C181.

Mihailidou AS, Bundgaard H, Mardini M, Hansen PS, Kjeldsen K \& Rasmussen HH 2000 Hyperaldosteronemia in rabbits inhibits the cardiac sarcolemmal $\mathrm{Na}^{+}-\mathrm{K}^{+}$pump. Circulation Research 86 37-42. (doi:10.1161/01.RES.86.1.37)

Mihailidou AS, Mardini M, Funder JW \& Raison M 2002 Mineralocorticoid and angiotensin receptor antagonism during hyperaldosteronemia. Hypertension 40 124-129. (doi:10.1161/01. HYP.0000025904.23047.27)

Mihailidou AS, Mardini M \& Funder JW 2004 Rapid, nongenomic effects of aldosterone in the heart mediated by \{epsilon\} protein kinase C. Endocrinology 145 773-780. (doi:10.1210/en.2003-1137)

Mihailidou AS, Loan Le TY, Mardini M \& Funder JW 2009 Glucocorticoids activate cardiac mineralocorticoid receptors during experimental myocardial infarction. Hypertension 54 1306. (doi:10.1161/ HYPERTENSIONAHA.109.136242)

Min LJ, Mogi M, Li JM, Iwanami J, Iwai M \& Horiuchi M 2005 Aldosterone and angiotensin II synergistically induce mitogenic response in vascular smooth muscle cells. Circulation Research $\mathbf{9 7}$ 434-442. (doi:10.1161/01.RES.0000180753.63183.95)

Min LJ, Mogi M, Iwanami J, Li JM, Sakata A, Fujita T, Tsukuda K, Iwai M \& Horiuchi M 2007 Cross-talk between aldosterone and angiotensin II in vascular smooth muscle cell senescence. Cardiovascular Research $\mathbf{7 6}$ 506-516. (doi:10.1016/j.cardiores.2007.07.008)

Mitts TF, Bunda S, Wang Y \& Hinek A 2010 Aldosterone and mineralocorticoid receptor antagonists modulate elastin and collagen deposition in human skin. Journal of Investigative Dermatology 130 2396-2406. (doi:10.1038/jid.2010.155)

Miyata Y, Muto S \& Kusano E 2005 Mechanisms for nongenomic and genomic effects of aldosterone on $\mathrm{Na}+\mathrm{H}+$ exchange in vascular smooth muscle cells. Journal of Hypertension 12 2237-2250. (doi:10.1097/01.hjh.0000194122.27475.6c)

Montezano AC, Callera GE, Yogi A, He Y, Tostes RC, He G, Schiffrin EL \& Touyz RM 2008 Aldosterone and angiotensin II synergistically stimulate migration in vascular smooth muscle cells through c-Src-regulated redox-sensitive RhoA pathways. Arteriosclerosis, Thrombosis, and Vascular Biology 28 1511-1518. (doi:10.1161/ATVBAHA.108.168021)

Moreau, Chardigny J \& Rochette L 1996 Effects of aldosterone and spironolactone on the isolated perfused rat heart. Pharmacology $\mathbf{5 3}$ 28-36. (doi:10.1159/000139412)

Published by Bioscientifica Ltd. 
Moura AM \& Worcel M 1984 Direct action of aldosterone on transmembrane $22 \mathrm{Na}$ efflux from arterial smooth muscle. Rapid and delayed effects. Hypertension 6 425-430. (doi:10.1161/01.HYP.6.3.425)

Musch MW, Lucioni A \& Chang EB 2008 Aldosterone regulation of intestinal Na absorption involves SGK-mediated changes in NHE3 and $\mathrm{Na}(+)$ pump activity. American Journal of Physiology: Gastrointestinal and Liver Physiology 295 G909-G919. (doi:10.1152/ajpgi.90312.2008)

Mutoh A, Isshiki M \& Fujita T 2008 Aldosterone enhances ligandstimulated nitric oxide production in endothelial cells. Hypertension Research 31 1811-1820. (doi:10.1291/hypres.31.1811)

Nagata D, Takahashi M, Sawai K, Tagami T, Usui T, Shimatsu A, Hirata Y \& Naruse M 2006 Molecular mechanism of the inhibitory effect of aldosterone on endothelial NO synthase activity. Hypertension $\mathbf{4 8}$ 165-171. (doi:10.1161/01.HYP.0000226054.53527.bb)

Nakano S, Kobayashi N, Yoshida K, Ohno T \& Matsuoka H 2005 Cardioprotective mechanisms of spironolactone associated with the angiotensin-converting enzyme/epidermal growth factor receptor/ extracellular signal-regulated kinases, NAD(P)H oxidase/lectin-like oxidized low-density lipoprotein receptor-1, and rho-kinase pathways in aldosterone/salt-induced hypertensive rats. Hypertension Research 28 925-936. (doi:10.1291/hypres.28.925)

Neves MF, Virdis A \& Schiffrin EL 2003 Resistance artery mechanics and composition in angiotensin II-infused rats: effects of aldosterone antagonism. Journal of Hypertension 21 189-198. (doi:10.1097/00004872-200301000-00029)

Neves MF, Amiri F, Virdis A, Diep QN \& Schiffrin EL 2005 Role of aldosterone in angiotensin II-induced cardiac and aortic inflammation, fibrosis, and hypertrophy. Canadian Journal of Physiology and Pharmacology 83 999-1006. (doi:10.1139/y05-068)

Nguyen Dinh Cat A \& Jaisser F 2012 Extrarenal effects of aldosterone. Current Opinion in Nephrology and Hypertension 21 147-156. (doi:10.1097/MNH.0b013e32834fb25b)

Nietlispach F, Julius B, Schindler R, Bernheim A, Binkert C, Kiowski W \& Brunner-La Rocca HP 2007 Influence of acute and chronic mineralocorticoid excess on endothelial function in healthy men. Hypertension 50 82-88. (doi:10.1161/ HYPERTENSIONAHA.107.088955)

Oberfeld B, Ruffieux-Daidie D, Vitagliano JJ, Pos KM, Verrey F \& Staub O 2011 Ubiquitin-specific protease 2-45 (Usp2-45) binds to epithelial $\mathrm{Na}+$ channel (ENaC)-ubiquitylating enzyme Nedd4-2. American Journal of Physiology: Renal Physiology 301 F189. (doi:10.1152/ ajprenal.00487.2010)

Okoshi MP, Yan X, Okoshi K, Nakayama M, Schuldt AJT, O'Connell TD, Simpson PC \& Lorell BH 2004 Aldosterone directly stimulates cardiac myocyte hypertrophy. Journal of Cardiac Failure 10 511-518. (doi:10.1016/j.cardfail.2004.03.002)

Pavlov TS, Levchenko V \& Staruschenko A 2014 Role of Rho GDP dissociation inhibitor alpha in control of epithelial sodium channel (ENaC)-mediated sodium reabsorption. Journal of Biological Chemistry 289 28651-28659. (doi:10.1074/jbc.M114.558262)

Pinto V, Pinho MJ, Hopfer U, Jose PA \& Soares-da-Silva PC 2008 Oxidative stress and the genomic regulation of aldosterone-stimulated NHE1 activity in SHR renal proximal tubular cells. Molecular and Cellular Biochemistry 310 191-201. (doi:10.1007/s11010-007-9680-6)

Pitt B, Zannad F, Remme WJ, Cody R, Castaigne A, Perez A, Palensky J \& Wittes J 1999 The effect of spironolactone on morbidity and mortality in patients with severe heart failure. Randomized Aldactone Evaluation Study Investigators. New England Journal of Medicine 341 709-717. (doi:10.1056/NEJM199909023411001)

Pitt B, Remme W, Zannad F, Neaton J, Martinez F, Roniker B, Bittman R, Hurley S, Kleiman J \& Gatlin M 2003a Eplerenone, a selective aldosterone blocker, in patients with left ventricular dysfunction after myocardial infarction. New England Journal of Medicine 348 1309-1321. (doi:10.1056/NEJMoa030207)

Pitt B, Reichek N, Willenbrock R, Zannad F, Phillips RA, Roniker B, Kleiman J, Krause S, Burns D \& Williams GH $2003 b$ Effects of eplerenone, enalapril, and eplerenone/enalapril in patients with essential hypertension and left ventricular hypertrophy: the 4E-left ventricular hypertrophy study. Circulation 108 1831-1838. (doi:10.1161/01.CIR.0000091405.00772.6E)

Pitt B, Pfeffer MA, Assmann SF, Boineau R, Anand IS, Claggett B, Clausell N, Desai AS, Diaz R, Fleg JL, et al. 2014 Spironolactone for heart failure with preserved ejection fraction. New England Journal of Medicine 370 1383-1392. (doi:10.1056/NEJMoa1313731)

Pochynyuk O, Medina J, Gamper N, Genth H, Stockand JD \& Staruschenko A 2006 Rapid translocation and insertion of the epithelial $\mathrm{Na}+$ channel in response to RhoA signaling. Journal of Biological Chemistry 281 26520-26527. (doi:10.1074/jbc.M603716200)

Pochynyuk O, Staruschenko A, Bugaj V, LaGrange L \& Stockand JD 2007 Quantifying RhoA facilitated trafficking of the epithelial $\mathrm{Na}+$ channel toward the plasma membrane with total internal reflection fluorescence-fluorescence recovery after photobleaching. Journal of Biological Chemistry 282 14576-14585. (doi:10.1074/jbc.M701348200)

Pojoga LH, Adamova Z, Kumar A, Stennett AK, Romero JR, Adler GK Williams GH \& Khalil RA $2010 a$ Sensitivity of NOS-dependent vascular relaxation pathway to mineralocorticoid receptor blockade in caveolin-1-deficient mice. American Journal of Physiology: Heart and Circulatory Physiology 298 H1776. (doi:10.1152/ajpheart.00661.2009)

Pojoga LH, Romero JR, Yao TM, Loutraris P, Ricchiuti V, Coutinho P, Guo C, Lapointe N, Stone JR, Adler GK, et al. 2010b Caveolin-1 ablation reduces the adverse cardiovascular effects of $\mathrm{N}$-w-Nitro-l-arginine methyl ester and angiotensin II. Endocrinology 151 1236-1246. (doi:10.1210/en.2009-0514)

Pojoga LH, Underwood PC, Goodarzi MO, Williams JS, Adler GK, Jeunemaitre X, Hopkins PN, Raby BA, Lasky-Su J, Sun B, et al. 2011 Variants of the caveolin-1 gene: a translational investigation linking insulin resistance and hypertension. Journal of Clinical Endocrinology Metabolism 96 E1288-E1292. (doi:10.1210/jc.2010-2738)

Pojoga LH, Coutinho P, Rivera A, Yao TM, Maldonado ER, Youte R, Adler GK, Williams J, Turchin A, Williams GH, et al. 2012 Activation of the mineralocorticoid receptor increases striatin levels. American Journal of Hypertension 25 243-249. (doi:10.1038/ajh.2011.197)

Preston IR, Sagliani KD, Warburton RR, Hill NS, Fanburg BL \& Jaffe IZ 2013 Mineralocorticoid receptor antagonism attenuates experimental pulmonary hypertension. American Journal of Physiology: Lung Cellular and Molecular Physiology 304 L678-L688.

Prossnitz ER \& Hathaway HJ 2015 What have we learned about GPER function in physiology and disease from knockout mice? Journal of Steroid Biochemistry and Molecular Biology 153 114-126. (doi:10.1016/j. jsbmb.2015.06.014)

Ren Y, Ambrosio MA, Garvin JL, Leung P, Kutskill K, Wang H, Peterson EL \& Carretero OA 2014 Aldosterone sensitizes connecting tubule glomerular feedback via the aldosterone receptor GPR30. American Journal of Physiology: Renal Physiology 307 F427. (doi:10.1152/ ajprenal.00072.2014)

Ricchiuti V, Lapointe N, Pojoga L, Yao T, Tran L, Williams GH \& Adler GK 2011 Dietary sodium intake regulates angiotensin II type 1, mineralocorticoid receptor, and associated signaling proteins in heart. Journal of Endocrinology 211 47-54. (doi:10.1530/JOE-10-0458)

Rigiracciolo DC, Scarpelli A, Lappano R, Pisano A, Santolla MF, Avino S, De Marco P, Bussolati B, Maggiolini M \& De Francesco EM 2016 GPER is involved in the stimulatory effects of aldosterone in breast cancer cells and breast tumor-derived endothelial cells. Oncotarget 7 94-111. (doi:10.18632/oncotarget.6475)

Romagni P, Rossi F, Guerrini L, Quirini C \& Santiemma V 2003 Aldosterone induces contraction of the resistance arteries in man. Atherosclerosis 166 345-349. (doi:10.1016/S0021-9150(02)00363-5)

Roy JW, Hill E, Ruan YC, Vedovelli L, P-âunescu TG, Brown D \& Breton S 2013 Circulating aldosterone induces the apical accumulation of the proton pumping V-ATPase and increases proton secretion in clear cells in the caput epididymis. American Journal of Physiology: Cell Physiology 305 C436-C446. (doi:10.1152/ajpcell.00410.2012) 
Rude MK, Duhaney TA, Kuster GM, Judge S, Heo J, Colucci WS, Siwik DA \& Sam F 2005 Aldosterone stimulates matrix metalloproteinases and reactive oxygen species in adult rat ventricular cardiomyocytes Hypertension 46 555-561. (doi:10.1161/01.HYP.0000176236.55322.18)

Sanz-Rosa D, Oubina MP, Cediel E, Heras NDL, Aragoncillo P, Balfagon G, Cachofeiro V \& Lahera V 2005 Eplerenone reduces oxidative stress and enhances eNOS in SHR: vascular functional and structural consequences. Antioxidants and Redox Signaling 7 1294-1301. (doi:10.1089/ars.2005.7.1294)

Schmidt BMW, Montealegre A, Janson CP, Martin N, Stein-Kemmesies C, Scherhag A, Feuring M, Christ M \& Wehling M 1999 Short term cardiovascular effects of aldosterone in healthy male volunteers. Journal of Clinical Endocrinology and Metabolism 84 3528-3533. (doi:10.1210/jc.84.10.3528)

Schmidt BMW, Georgens AC, Martin N, Tillmann H-C, Feuring M, Christ M \& Wehling M 2001 Interaction of rapid nongenomic cardiovascular aldosterone effects with the adrenergic system. Journal of Clinical Endocrinology and Metabolism 86 761-767. (doi:10.1210/jc.86.2.761)

Schmidt BM, Oehmer S, Delles C, Bratke R, Schneider MP, Klingbeil A, Fleischmann EH \& Schmieder RE 2003 Rapid nongenomic effects of aldosterone on human forearm vasculature. Hypertension 42 156-160. (doi:10.1161/01.HYP.0000083298.23119.16)

Schmidt BM, Sammer U, Fleischmann I, Schlaich M, Delles C \& Schmieder RE 2006 Rapid nongenomic effects of aldosterone on the renal vasculature in humans. Hypertension 47 650-655. (doi:10.1161/01.HYP.0000205224.58715.cc)

Sherajee SJ, Fujita Y, Rafiq K, Nakano D, Mori H, Masaki T, Hara T, Kohno M, Nishiyama A \& Hitomi H 2012 Aldosterone induces vascular insulin resistance by increasing insulin-like growth factor-1 receptor and hybrid receptor. Arteriosclerosis, Thrombosis, and Vascular Biology 32 257. (doi:10.1161/ATVBAHA.111.240697)

Shibata S, Nagase M, Yoshida S, Kawarazaki W, Kurihara H, Tanaka H, Miyoshi J, Takai Y \& Fujita T 2008 Modification of mineralocorticoid receptor function by Rac1 GTPase: implication in proteinuric kidney disease. Nature Medicine 14 1370-1376. (doi:10.1038/nm.1879)

Shibata S, Mu S, Kawarazaki H, Muraoka K, Ishizawa Ki, Yoshida S, Kawarazaki W, Takeuchi M, Ayuzawa N, Miyoshi J, et al. 2011 Rac1 GTPase in rodent kidneys is essential for salt-sensitive hypertension via a mineralocorticoid receptor-dependent pathway. Journal of Clinical Investigation 121 3233-3243. (doi:10.1172/JCI43124)

Spach C \& Streeten DHP 1964 Retardation of sodium exchange in dog erythrocytes by physiological concentrations of aldosterone, in vitro*. Journal of Clinical Investigation 43 217-227. (doi:10.1172/ JCI104906)

Staruschenko A, Patel P, Tong Q, Medina JL \& Stockand JD 2004 Ras activates the epithelial $\mathrm{Na}+$ channel through phosphoinositide $3-\mathrm{OH}$ kinase signaling. Journal of Biological Chemistry 279 37771-37778. (doi:10.1074/jbc.M402176200)

Stockand JD, Edinger RS, Eaton DC \& Johnson JP 2000 Toward understanding the role of methylation in aldosterone-sensitive $\mathrm{Na}+$ transport. Physiology 15161.

Sugiyama T, Yoshimoto T, Tsuchiya K, Gochou N, Hirono Y, Tateno T, Fukai N, Shichiri M \& Hirata Y 2005 Aldosterone induces angiotensin converting enzyme gene expression via a JAK2-dependent pathway in rat endothelial cells. Endocrinology 146 3900-3906. (doi:10.1210/ en.2004-1674)

Summa V, Mordasini D, Roger F, Bens M, Martin PY, Vandewalle A, Verrey F \& Féraille E 2001 Short term effect of aldosterone on Na,K-ATPase cell surface expression in kidney collecting duct cells. Journal of Biological Chemistry 276 47087-47093. (doi:10.1074/jbc.M107165200)

Summa V, Camargo SMR, Bauch C, Zecevic M \& Verrey F 2004 Isoform specificity of human $\mathrm{Na}+, \mathrm{K}+$-ATPase localization and aldosterone regulation in mouse kidney cells. Journal of Physiology 555 355-364. (doi:10.1113/jphysiol.2003.054270)

Thomas SR, Schulz E \& Keaney J 2006 Hydrogen peroxide restrains endothelium-derived nitric oxide bioactivity - role for iron-

http://joe.endocrinology-journals.org

DOI: 10.1530/JOE-16-0659
๑) 2017 Society for Endocrinology Printed in Great Britain dependent oxidative stress. Free Radical Biology and Medicine 41 681-688. (doi:10.1016/j.freeradbiomed.2006.05.012)

Tillmann HC, Schumacher B, Yasenyev O, Junker M, Christ M, Feuring M \& Wehling M 2002 Acute effects of aldosterone on intracardiac monophasic action potentials. International Journal of Cardiology $\mathbf{8 4}$ 33-39. (doi:10.1016/S0167-5273(02)00115-8)

Tsai CF, Yang SF, Chu HJ \& Ueng KC 2013 Cross-talk between mineralocorticoid receptor/angiotensin II type 1 receptor and mitogen-activated protein kinase pathways underlies aldosteroneinduced atrial fibrotic responses in HL-1 cardiomyocytes. International Journal of Cardiology 169 17-28. (doi:10.1016/j.ijcard.2013.06.046)

Uhrenholt TR, Schjerning J, Hansen PB, Norregaard R, Jensen BL, Sorensen GL \& Skott O 2003 Rapid inhibition of vasoconstriction in renal afferent arterioles by aldosterone. Circulation Research 93 1258-1266. (doi:10.1161/01.RES.0000106135.02935.E1)

Ullian ME, Schelling JR \& Linas SL 1992 Aldosterone enhances angiotensin II receptor binding and inositol phosphate responses. Hypertension 20 67-73. (doi:10.1161/01.HYP.20.1.67)

Ullian ME, Walsh LG \& Morinelli TA 1996 Potentiation of angiotensin II action by corticosteroids in vascular tissue. Cardiovascular Research $\mathbf{3 2}$ 266-273. (doi:10.1016/0008-6363(96)00053-3)

Ushio-Fukai M \& Alexander RW 2006 Caveolin-dependent angiotensin II type 1 receptor signaling in vascular smooth muscle. Hypertension $\mathbf{4 8}$ 797. (doi:10.1161/01.HYP.0000242907.70697.5d)

Vecchiola A, Lagos CF, Carvajal CA, Baudrand R \& Fardella CE 2016 Aldosterone production and signaling dysregulation in obesity. Current Hypertension Reports 18 20. (doi:10.1007/s11906-016-0626-9)

Virdis A, Neves MF, Amiri F, Viel E, Touyz RM \& Schiffrin EL 2002 Spironolactone improves angiotensin-induced vascular changes and oxidative stress. Hypertension 40 504-510. (doi:10.1161/01. HYP.0000034738.79310.06)

Wang Q, Cui W, Zhang HL, Hu HJ, Zhang YN, Liu DM \& Liu J 2013 Atorvastatin suppresses aldosterone-induced neonatal rat cardiac fibroblast proliferation by inhibiting ERK1/2 in the genomic pathway. Journal of Cardiovascular Pharmacology 61 520-527. (doi:10.1097/ FJC.0b013e31828c090e)

Watts BA, III, George T \& Good DW 2006 Aldosterone inhibits apical NHE3 and HCO3- absorption via a nongenomic ERK-dependent pathway in medullary thick ascending limb. American Journal of Physiology: Renal Physiology 291 F1005-F1013. (doi:10.1152/ ajprenal.00507.2005)

Wehling M, Käsmayr J \& Theisen K 1991 Rapid effects of mineralocorticoids on sodium-proton exchanger: genomic or nongenomic pathway? American Journal of Physiology 260 E719-E726.

Wehling M, Eisen C, Aktas J, Christ M \& Theisen K 1992 Photoaffinity labeling of plasma membrane receptors for aldosterone from human mononuclear leukocytes. Biochemical and Biophysical Research Communications 189 1424-1428. (doi:10.1016/0006291X(92)90233-B)

Wehling M, Ulsenheimer A, Schneider M, Neylon C \& Christ M 1994 Rapid effects of aldosterone on free intracellular calcium in vascular smooth muscle and endothelial cells: subcellular localization of calcium elevations by single cell imaging. Biochemical and Biophysical Research Communications 204 475-481. (doi:10.1006/bbrc.1994.2484)

Wehling M, Spes CH, Win N, Janson CP, Schmidt BMW, Theisen K \& Christ M 1998 Rapid cardiovascular action of aldosterone in man. Journal of Clinical Endocrinology and Metabolism 83 3517-3522. (doi:10.1210/jc.83.10.3517)

Wildling L, Hinterdorfer P, Kusche-Vihrog K, Treffner Y \& Oberleithner H 2008 Aldosterone receptor sites on plasma membrane of human vascular endothelium detected by a mechanical nanosensor. Pfluegers Archiv: European Journal of Physiology 458 223. (doi:10.1007/s00424-008-0615-1)

Winter C, Schulz N, Giebisch G, Geibel JP \& Wagner CA 2004 Nongenomic stimulation of vacuolar H+-ATPases in intercalated renal tubule cells by aldosterone. PNAS 101 2636-2641. (doi:10.1073/ pnas.0307321101)

Published by Bioscientifica Ltd. 
Xiao F, Puddefoot JR, Barker S \& Vinson GP 2004 Mechanism for aldosterone potentiation of angiotensin II-stimulated rat arterial smooth muscle cell proliferation. Hypertension 44 340-345. (doi:10.1161/01.HYP.0000140771.21243.ed)

Xue B, Beltz TG, Yu Y, Guo F, Gomez-Sanchez CE, Hay M \& Johnson AK 2011 Central interactions of aldosterone and angiotensin II in aldosterone- and angiotensin II-induced hypertension. American Journal of Physiology: Heart and Circulatory Physiology 300 H555-H564.

Yamada M, Kushibiki M, Osanai T, Tomita H \& Okumura K 2008 Vasoconstrictor effect of aldosterone via angiotensin II type 1 (AT1) receptor: possible role of AT1 receptor dimerization. Cardiovascular Research 79 169. (doi:10.1093/cvr/cvn064)

Yang Y, Ma Z, Hu W, Wang D, Jiang S, Fan C, Di S, Liu D, Sun Y \& Yi W 2016 Caveolin-1/-3: therapeutic targets for myocardial ischemia/ reperfusion injury. Basic Research in Cardiology 111 45. (doi:10.1007/ s00395-016-0561-6)

Young M \& Funder J 2003 Mineralocorticoid action and sodiumhydrogen exchange: studies in experimental cardiac fibrosis. Endocrinology 144 3848-3851. (doi:10.1210/en.2003-0039)

Young M, Fullerton M, Dilley R \& Funder J 1994 Mineralocorticoids, hypertension, and cardiac fibrosis. Journal of Clinical Investigation 93 2578-2583. (doi:10.1172/JCI117269)

Yu Z, Kong Q \& Kone B 2013 Aldosterone reprograms promoter methylation to regulate aENaC transcription in the collecting duct. American Journal of Physiology: Renal Physiology 305 F1006-F1013. (doi:10.1152/ajprenal.00407.2013)

Zannad F, McMurray JJV, Krum H, van Veldhuisen DJ, Swedberg K, Shi H, Vincent J, Pocock SJ \& Pitt B 2010 Eplerenone in patients with systolic heart failure and mild symptoms. New England Journal of Medicine 364 11-21. (doi:10.1056/NEJMoa1009492)

Zennaro MC, Le Menuet D \& Lombes M 1996 Characterization of the human mineralocorticoid receptor gene 5 '-regulatory region: evidence for differential hormonal regulation of two alternative promoters via nonclassical mechanisms. Molecular Endocrinology 10 1549-1560. (doi:10.1210/me.10.12.1549)

Zhang W, Xia X, Reisenauer MR, Hemenway CS \& Kone BC 2006 Dot1a-AF9 complex mediates histone H3 Lys-79 hypermethylation and repression of $\mathrm{ENaC}$ alpha in an aldosterone-sensitive manner. Journal of Biological Chemistry 281 18059-18068. (doi:10.1074/jbc. M601903200)

Zhang W, Xia X, Reisenauer MR, Rieg T, Lang F, Kuhl D, Vallon V \& Kone BC 2007 Aldosterone-induced Sgk1 relieves Dot1a-Af9mediated transcriptional repression of epithelial $\mathrm{Na}(+)$ channel alpha. Journal of Clinical Investigation 117 773-783. (doi:10.1172/ JCI29850)

Zhang M, Chen J, Lai L, You L, Lin S, Hao C \& Gu Y 2010 Aldosterone promotes fibronectin synthesis in rat mesangial cells via ERK1/2stimulated $\mathrm{Na}-\mathrm{H}+$ exchanger isoform 1. American Journal of Nephrology 31 75-82. (doi:10.1159/000256665)

Zhang ZH, Yu Y, Wei SG \& Felder RB 2012 Aldosterone-induced brain MAPK signaling and sympathetic excitation are angiotensin II type-1 receptor dependent. American Journal of Physiology: Heart and Circulatory Physiology 302 H742. (doi:10.1152/ajpcell.00004.2012)

Zhou ZH \& Bubien JK 2001 Nongenomic regulation of ENaC by aldosterone. American Journal of Physiology: Cell Physiology $\mathbf{2 8 1}$ C1118-C1130.

Received in final form 21 March 2017

Accepted 27 March 2017

Accepted Preprint published online 27 March 2017
(C) 2017 Society for Endocrinology Printed in Great Britain
Published by Bioscientifica Ltd. 